\title{
Integrated Hydrological-Hydraulic Model for Flood Simulation in Tropical Urban Catchment
}

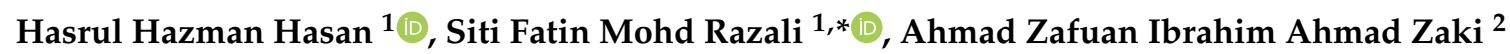 \\ and Firdaus Mohamad Hamzah ${ }^{1}$ \\ 1 Smart and Sustainable Township Research Centre, Faculty of Engineering \& Built Environment, Universiti \\ Kebangsaan Malaysia, UKM Bangi 43600, Selangor, Malaysia; P99749@siswa.ukm.edu.my (H.H.H.); \\ fir@ukm.edu.my (F.M.H.) \\ 2 ZHL Engineers Sdn. Bhd., Presint Diplomatik 15, Putrajaya 62502, Malaysia; Zafuan@zhl-engineers.com \\ * Correspondence: fatinrazali@ukm.edu.my; Tel.: +60-38-9216-216
}

Received: 21 October 2019; Accepted: 20 November 2019; Published: 27 November 2019

\begin{abstract}
In recent decades, Malaysia has become one of the world's most urbanized nations, causing severe flash flooding. Urbanization should meet the population's needs by increasing the development of paved areas, which has significantly changed the catchment's hydrological and hydraulic characteristics. Therefore, the frequency of flash flooding in Malaysia's urban areas has grown year after year. Numerous techniques have been used, including the statistical approach, modeling, and storm design methods, in flood simulation. This research integrated hydrology and hydraulic models to simulate the urban flood events in the Aur River catchment. The primary objective is to determine water level and forecast peak flow based on hydrological assessment in the drainage system using XPSWMM software. The rainfall data for $60 \mathrm{~min}$ was used for this study in the hydrological analysis by obtaining an intensity-duration-frequency curve and peak flow value (Q peak). XPSWMM is used to simulate the response of a catchment to rainfall events in which runoff, water depth profile, and outflow hydrograph are obtained. Peak runoff is also obtained from the modified rational method for validation purposes. The proposed method was verified by comparing the result with the standard method. This is essential to identify flash flooding, which can lead to efficient flood mitigation planning and management in the urban catchment. The increase in residential areas results in the alteration of time of concentration, water quantity, and flow rate. Thus, to mitigate present and future problems, the effects of urbanization on water resources and flood should be analyzed.
\end{abstract}

Keywords: flood prediction; urban flood; XPSWMM; tropical catchment; stormwater management

\section{Introduction}

Flood is a frequent natural disaster and can cause adversity to the country and people. Urban flood is a complicated phenomenon owing to the inhomogeneity of the urban surface [1]. Over the past few decades, urban flood intensity has risen worldwide in response to two primary factors-urbanization and climate change [2,3]. The effect of urbanization on local urban flooding is more important than climate change $[4,5]$. Urban flooding generally happens when heavy rainfall is immediately followed by a restricted drainage system capability [6]. Depending on the drainage system, particular drainage layout features, and specific local limitations, flooding in the urban catchment may happen at different phases of the hydraulic surcharge [7]. An urban flood may trigger damage to the structure, environment, impact people's daily life, and can be catastrophic in extreme instances. Consequently, it is not remarkable that the global authorities are interested in flood prevention and mitigation to 
address this devastating effect [8]. Therefore, urban flood prediction and simulation are essential for reducing and preventing the damage from urban flood crises.

The increase in population and economic growth with the changing development trend has resulted in an unprecedented expansion of urbanized land. Over the past three decades, Malaysia has seen an increase of almost $30-40 \%$ in urban expansion [9]. Although serving as the economic and population centers, urban areas have significant adverse environmental impacts, both within and beyond the urban boundaries. In the 21st century, most of the climate models and empirical evidence show that warmer climate increases atmospheric water vapor, which leads to more intense and more frequent precipitation events [3]. The size of the conventional drainage system is calculated based on historical precipitation data, assuming the precipitation frequency and intensity will remain unchanged over the system's design life. Since climate change results in increased rainfall intensity and frequency, the assumption becomes incorrect, and the faulty assumption-based design capacity becomes too small to accommodate increased rainfall [10]. The failure of urban drainage systems due to extreme precipitation and the subsequent massive damage in the socio-economic systems and other infrastructures such as buildings, roads, and underground utilities have been increasingly evidenced in many cities [11,12]. The flood simulation in the watershed catchment is used to simulate hydrology and evaluate the impacts of urban development $[13,14]$. Usually, flood modeling is conducted in a catchment to evaluate the effectiveness of watershed management. Flood simulation is used a quantitatively simulate flooding that can occur in order to solve urban flood catastrophes and identify the main problems in drainage systems where flooding can occur according to the simulation results [15]. The stormwater management model (SWMM) is widely used in rainfall and flood simulation and water pollution analysis in urban areas because it is capable of simulating conveyance systems [13].

Flash flood is distinguished by a failure of drainage management when heavy rainfall takes place in a metropolitan area when there is limited accessibility to the land that can be used to store water [16]. High-intensity rainfall may trigger flooding if the municipal sewage system and drainage channels do not have the ability to transport the surface runoff [2]. The industrialization and development of a country will surely bring about environmental disaster if there is no sustainable planning before commencing development [17]. Malaysia is a rapidly developing country, both physically and economically, and evidence shows that the danger of flooding is worsening due to development and urbanization $[18,19]$. Malaysia is among the countries with heavy rainfall throughout the year, and the most prevalent catastrophe in Malaysia is flooding $[19,20]$. On the eastern coast of Malaysia, flooding occurred primarily during the wet season, mainly driven by the north-eastern monsoon [21]. According to Ngai [22], $9 \%$ or $29,800 \mathrm{~km}^{2}$ of Malaysia's land region is easily affected by floods.

Intensive construction of housing and commercial operations focused on the catchment of the Aur River in recent years has resulted in the city and its surrounding regions being susceptible to flash flooding. There have been several flood events recorded within the Aur River catchment starting from 1999 to 2014 [23]. Commonly, the flooding issues in an urban area are caused by heavy rainfall and insufficient drainage capacity [10]. As a result, the low-lying areas located near the river are inundated. This study aims to determine the hydrological and hydraulic characteristics of the Aur River catchment. Next, it aims to analyze the runoff level and peak discharge using XPSWMM software. Finally, it aims to simulate and predict the flash flood based on temporal patterns in the Aur River catchment. This study is vital to understand the urban flooding, which can help in the planning and effective management of flood mitigation measures, and therefore, a thorough approach to modeling flooding in urban watersheds should be established.

\section{Materials and Methods}

Rainfall data were obtained from the Department of Irrigation and Drainage, Malaysia. There are four rainfall stations at the Aur River catchment. Table 1 represents the rainfall stations of the Aur River catchment. The average and maximum values of annual rainfall for each year were calculated. 
The maximum annual rainfall is one of the essential parameters in hydrological studies that can be used for flood design purposes [24].

Table 1. Rainfall stations at the Aur River catchment.

\begin{tabular}{ccccc}
\hline Station ID & Station Name & Period Records & Longitude & Latitude \\
\hline 2915117 & Sek. Men. Jalan Kebun & $2006-2016$ & $02^{\circ} 58^{\prime} 53^{\prime \prime}$ & $101^{\circ} 30^{\prime} 22^{\prime \prime}$ \\
3014091 & UiTM Shah Alam & $2001-2016$ & $03^{\circ} 02^{\prime} 52^{\prime \prime}$ & $101^{\circ} 26^{\prime} 53^{\prime \prime}$ \\
3014092 & Sek. Men. Raja Lumu & $2005-2016$ & $02^{\circ} 59^{\prime} 26^{\prime \prime}$ & $101^{\circ} 24^{\prime} 46^{\prime \prime}$ \\
3014094 & Bt 4 Kg. Jawa (Sg. Kandis) & $2008-2016$ & $03^{\circ} 01^{\prime} 18^{\prime \prime}$ & $101^{\circ} 30^{\prime} 17^{\prime \prime}$ \\
\hline
\end{tabular}

\subsection{Site Description}

The catchment of the Aur River has a total area of about 3978 ha, with a single gated outlet discharging into the Klang River at a river distance of $10.6 \mathrm{~km}$ (Figure 1). The Aur River is a tributary of the Langat River within the Klang district of Selangor. The Langat River's total length is $200 \mathrm{~km}$, and the width of the main river ranges between $20 \mathrm{~m}$ and $52 \mathrm{~m}$ [25]. The Aur River catchment is located on the west coast of Peninsular Malaysia and is typically hot and wet throughout the year as Malaysia experiences tropical climate with a uniform high temperature, high relative humidity, moderate rainfall, and low wind [26,27]. The west coast of Peninsular Malaysia is subject to the convective storms generated by the inter-monsoon seasons in April and October with high rainfall. The south-west monsoon, which is generally from May to September, contributes less rainfall on the west coast of Peninsular Malaysia [28].

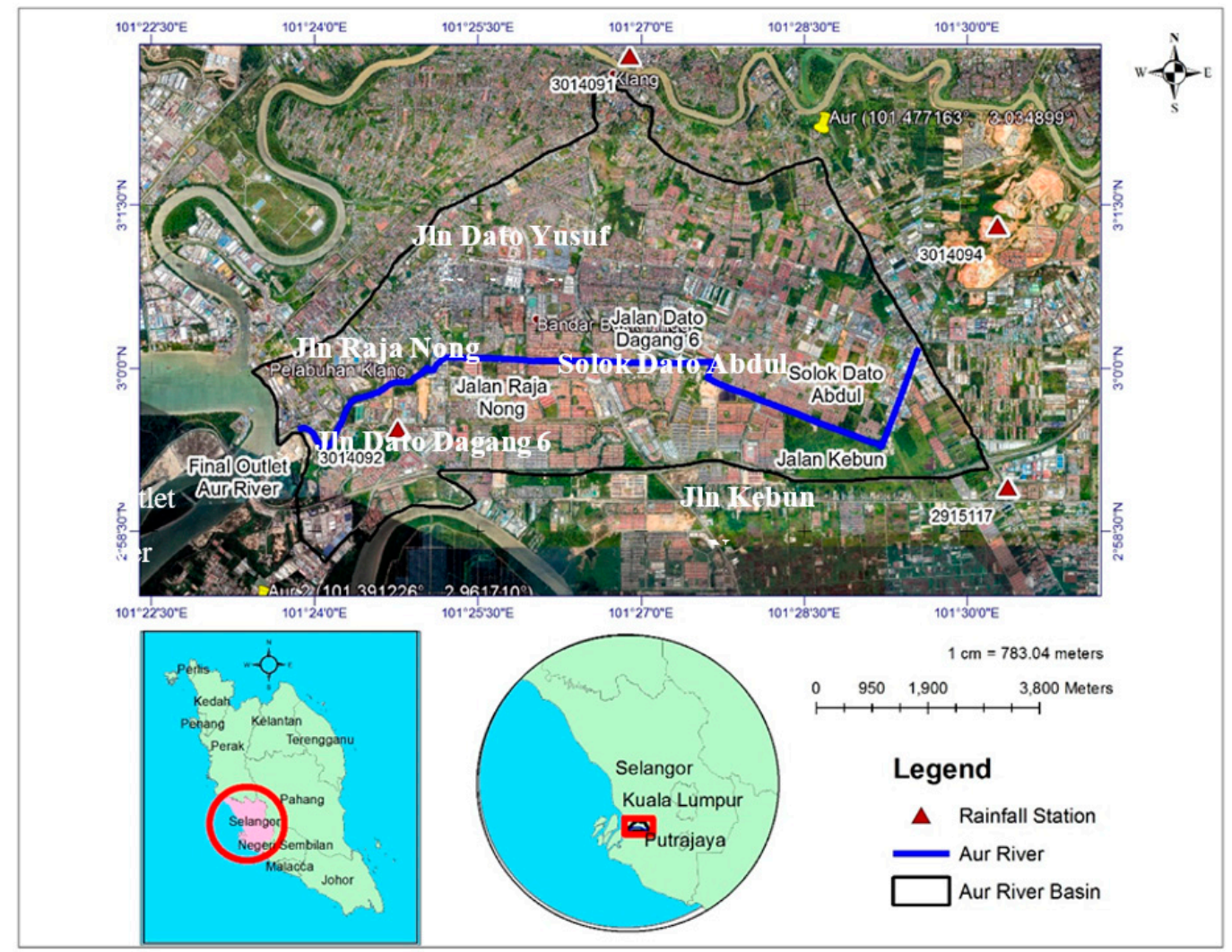

Figure 1. Location of the catchment boundary of Aur River, Malaysia.

The average annual rainfall depth varies from approximately more than $2500 \mathrm{~mm}$, with monthly variations. Throughout the year, the temperature is relatively uniform, between $24{ }^{\circ} \mathrm{C}$ and $33{ }^{\circ} \mathrm{C}$. Humidity in the lowlands is continuously high, ranging from $81 \%$ to $88 \%$ per annum. The rainstorms 
are isolated and generally of very high intensities, lasting for a short period. The Klang Local Plan 2002-2015 has delineated a detailed land use activity classifications base on the category of land use within the Aur River catchment [23]. Table 2 represents the existing land use zoning map for the Aur River and the extent of each type of land use (future land use) allowable based on the Draft of Local Plan of Klang Municipal Council 2020 [23]. The catchment is highly developed and comprised chiefly of residential, such as Bandar Puteri, Bandar Botanic, and Taman Sentosa, with some commercial land use [29]. An increase of surface runoff as a result of land use changes will have an adverse effect on the receiving water flow- quantity and quality, and ecology system of the catchment [30,31]. A study conducted by Yang et al. [32] was determined the land use from 1990 and 2009 in the Langat-Dengkil river sub-basin. The conversion of forest, grass, and wetlands at the Langat-Dengkil basin to urban areas usually comes with a vast increase in impermeable surface area, which shifts away from infiltration and decreasing the groundwater recharge, lowering the water tables [33]. It is expected that the current drainage system will not be able to cope with the constant changes in land use. The existing land use pattern for related sub-catchments will be used in the analysis to examine the current performance of the drainage system and to propose suitable measures to mitigate the problem. Urbanization disturbs natural landscapes; areas covered by plants are replaced by impermeable surfaces. Therefore, impermeable surfaces such as rooftops, parking lots, and roads decrease the ability for infiltration and increase the output of runoff in urban areas. Due to the rapid growth, effective conversion land cover change, and increased impervious surface in several areas will result in many issues and problems related to the flooding, especially at Bandar Puteri and Taman Sentosa [23,34].

Table 2. Distribution of land use at the Aur River catchment.

\begin{tabular}{lcccc}
\hline \multicolumn{1}{c}{ Landuse } & Existing Zoning & Percentage (\%) & Proposed Zoning & Percentage (\%) \\
\hline Residential & 780.35 & 27.09 & 1006.97 & 34.95 \\
Commercial & 46.85 & 1.63 & 75.63 & 2.63 \\
Industry & 266.65 & 9.26 & 969.76 & 33.66 \\
Agriculture & 338.12 & 11.74 & 192.23 & 6.67 \\
Forest & 62.84 & 2.18 & 16.80 & 0.58 \\
Vacant land & 594.06 & 20.62 & 0.00 & 0.00 \\
Institutional & 73.11 & 2.54 & 9.26 & 0.32 \\
Graveyard & 0.00 & 0.00 & 25.2 & 0.87 \\
Open Space & 4.69 & 0.16 & 8.86 & 0.31 \\
Special Uses & 0.00 & 0.00 & 54.76 & 1.90 \\
Transportation & 0.00 & 0.00 & 397.58 & 13.80 \\
Infrastructure \& Utility & 71.56 & 2.48 & 26.01 & 0.90 \\
Water Body & 0.00 & 0.00 & 73.35 & 2.55 \\
Under Construction & 466.29 & 16.19 & $0 / 00$ & 0.00 \\
Others & 176.27 & 6.12 & 24.38 & 0.85 \\
\hline Total & 2880.79 & 100.00 & 2880.79 & 100.00 \\
\hline
\end{tabular}

Source: Klang Municipal Council [23].

\subsection{Rainfall Frequency Analysis}

Analysis of rainfall frequency is a significant area of hydraulic engineering, planning, and the management of water resources [35]. This incorporates selecting interest objectives, sampling sample series, and selecting the most suitable distribution of the population. Analysis of extreme rainfall events was generally performed as a filter for abstracting maximum annual rainfall depths for analysis [36]. However, the dependence between rainfall properties is not considered by this univariate approach. Extreme rainfall analysis conducted using rainfall characteristics, like total depth, length, or duration and peak intensity, and a multivariate approach $[35,37,38]$.

The rainfall frequency analysis in this study is carried out using the graphical method. The plotting position for each station is done by applying the Weibull formula. Most hydrological variables are presumed to be continuous random processes, and prevalent constant distributions are required to 
fit historical records as in frequency analysis [16]. Extreme value theory considers the distribution of the observations according to the sample group. The recurrence intervals of excessive rainfall and flooding occurrences in the catchment of the Aur River are determined by using the Gumbel's extreme distribution. The cumulative distribution function of the density function for Gumbel was calculated using the following equation [39]:

$$
P(X \leq x)=F(x)=\exp \{-\exp [-\alpha(x-u)]\},
$$

which can be solved for the recurrence interval $T$ and the variate $x$, following Equations (2) and (3):

$$
\begin{gathered}
\frac{1}{T}=1-F(x)=1-\exp \{-\exp [-\alpha(x-u)]\}, \\
x=u-\frac{1}{\alpha} \ln [\ln T-\ln (T-1)],
\end{gathered}
$$

Substituting into the general frequency equation in Equation (4),

$$
X_{T}=\bar{x}+K_{T} s,
$$

where

$X_{T}=$ rainfall event for a given return period, $T$;

$\bar{x}=$ mean of the rainfall events;

$K_{T}=$ frequency factor of a rainfall event; and

$s=$ standard deviation of the rainfall event.

The frequency factor $K_{T}$ becomes Equation (5),

$$
K_{T}=-\frac{\sqrt{6}}{\pi}\left[0.5772+\ln \left\{\ln \left[\frac{T}{T-1}\right]\right\}\right],
$$

when $K_{T}=0, T=2.33$ years or exceedance probability of 0.43 , that is the recurrence interval of the mean annual flood.

When rainfall is higher than its mean value in a particular area, a flood is expected to occur. Frequency analysis can be determined through the probability distribution of rainfall on the rainfall pattern, which makes it essential to predict the probability of occurrence of rainfall from the historical records [40,41]. Rainfall frequency analysis was conducted to estimate how often a rainfall event will occur [42]. Frequency analysis includes fitting a probability for a sample of maximum rainfall over a specified period of time. The model parameters established are then used to predict the extreme events of a large recurrence interval. Reliable rainfall frequency estimates are necessary for flood management, proper designs of irrigation schemes, and for designing water modifications and infrastructures [12].

\subsection{Modified Rational Method}

Quantifying how much rainfall events are related to runoff, is a vital aspect of the development of the model of rainfall-runoff [43]. The estimation of the rainfall-runoff model can be done using a modified rational method. The modified rational method is an advance from the rational method by generating the hydrographs that related to rainfall-runoff events in a particular area [44]. Globally, the modified rational method was applied to determine 1400 rainfall-runoff events at 80 watersheds in Texas by developed hydrographs [45]. The modified rational method was adapted in Hydrological Procedure No. 16 (HP16): Flood Estimation for Urban Areas in Peninsular Malaysia by the Urban Drainage Unit of the Drainage and Irrigation Department, Malaysia [46]. The characteristics are required for flood estimation procedure to satisfy the following conditions: (1) estimate the design peak discharge, (2) produce a hydrograph of peak discharge, and (3) utilize input data from topographic and land use maps. 
There are some restrictions on the general rational method. It is often used for estimating peak runoff from impervious areas, and it is most accurate in small drainage basins $[45,47,48]$ but is rarely used in the estimation of direct runoff depth or volume. On the other hand, the modified rational method is the simplest method to estimate infiltration and runoff with precise physical characteristics [49]. Wang et al. [50] developed a modified rational method for arid-region runoff estimation. Del Giudice et al. [51] analyzed the spatial prediction of the runoff coefficient for flood index estimation and compared it with the rational method in Peninsular Italy.

The modified rational method is reliable for catchment sizes up to 150 acres. The integration of runoff and rainfall from other routing effects can be assumed that the runoff coefficient $C$ comprises of two main factors. Based on these characteristics, the modified rational method is the most suitable to estimate flood for the urban area [52]. The modified rational method is usually expressed in term of the following Equation (6):

$$
Q_{A R I}=C_{S} \times C \times I \times A,
$$

where

$Q_{A R I}=$ Peak discharge $\left(\mathrm{m}^{3} / \mathrm{s}\right)$;

$C_{S}=$ Storage coefficient;

$C=$ Runoff coefficient;

$I=$ Rate of rainfall intensity $(\mathrm{mm} / \mathrm{h}) ;$ and

$A=$ Drainage area (ha).

An accurate estimation of the runoff coefficient $C$ can be made using a rational method. In general, $C$ values depend on the catchment's land use and are very similar to its impermeability. The values of $C$ differ with soil type, condition of soil moisture, and intensity of rainfall. Within a sub-catchment, sections of different land use can be combined to generate an average runoff coefficient. For example, if a sub-catchment consists of segments with different land use denoted by $j=1,2, \ldots, m$; the average runoff coefficient is estimated following Equation (7), and the other parameter in the modified rational method is storage coefficient, $C_{S}$ is estimated by Equation (8),

$$
C_{a v g}=\frac{\sum_{j=1}^{m} C_{j} A_{j}}{\sum_{j=1}^{m} A_{j}},
$$

where

$C_{a v g}=$ Average runoff coefficient;

$C_{j}=$ Runoff coefficient of segment $i$;

$A_{j}=$ Area of segment $i($ ha); and

$m=$ Total number of segments.

$$
C_{S}=\frac{2 t_{c}}{2 t_{c}+t_{d}}
$$

where

$C_{S}=$ Storage coefficient;

$t_{c}=$ Time of concentration ( $\left.\mathrm{min}\right) ;$ and

$t_{d}=$ Time of flow in the channel (min).

\subsection{XPSWMM Modelling}

The Stormwater Management Model (SWMM) is a regularly applied model that contains a comprehensive simulation of hydrological and hydraulic in urban drainage systems [14,53,54]. SWMM was developed by the United States Environmental Protection Agency (EPA) in the 1970s, is publicly available, and is often revised [44]. SWMM conducts continuous event simulation and can undertake detailed quantity and quality modeling that can simulate an element of urban runoff, including surface and subsurface runoff, routing of the drainage system, and water storage. 
The XP Stormwater Management Model (XPSWMM) is a comprehensive 1D/2D modeling software created by XP Solutions. The hydrologic simulation of XPSWMM allows for the use of historical rainfall events or design storm events [55], and the hydraulic simulation of XPSWMM includes flow routing for conduits in dendritic and looped networks $[13,20]$. XPSWMM is capable of performing dynamic routing of stormwater flows through the drainage system to the outfall points [56]. Two modules-the hydrological and hydraulic simulation-are required for the simulation model. The catchment characteristics and precipitation data are required for hydrological simulation, while data such as drainage volume, size, slope, and elevation are needed for hydraulic simulation [13].

\subsubsection{Intensity-Duration-Frequency (IDF) Analysis}

The most effective method for determining the maximum rainfall event or design storm event is the use of rainfall intensity, duration, and frequency based on intensity-duration-frequency (IDF) curves $[14,38,57,58]$. It also generates an analysis of the rainfall characteristics of the site by relating the duration of the storm and the likelihood of exceeding the probability of rainfall intensity, which is supposed to be constant over time [6,59]. These methods rely on relevant information and accessible data.

An IDF curve illustrates the nativity relationship of the intensity, duration, and return period of rainfall. Since the 1960s, the intensity curve of the frequency period has been studied in several developing countries, and maps have been designed to provide the intensity of rainfall or depth for various periods and return periods [54,60]. An IDF curve is usually used in designing hydrological, hydraulic, and water source systems. An IDF curve is obtained through the analysis of rainfall observation frequency [42]. From the measurement of rainfall data, records for each year will be determined. The maximum duration of annual rain intensity will also be defined within a specified period or maximum annual rainfall depth over a specific period. The usual periods used for analysis are $5,10,15,30,60,120,360,720$, and $1440 \mathrm{~min}$. Intensity, duration, and return period are the parameters used to form the IDF curve. The intensity of rainfall distribution in the IDF curve is the average rainfall in the area where the rain gauges are located.

\subsubsection{Rainfall Temporal Pattern}

The regular rainfall temporal pattern must be derived for different storm durations to simulate flood hydrographs for different storm periods using the rainfall-runoff [14]. The temporal pattern represents the rainfall intensity variation through a typical storm's time of occurrence in the study area. This study used all available data to derive the temporal rainfall pattern, including recent storm events from a selection for a specific rainfall station of a large number of storm events. The temporal design patterns derived cover storm durations of 15, 30, 60, and $1440 \mathrm{~min}$.

\subsubsection{Double Mass Curve}

The verification of the consistency of hydrological information was conducted using a double mass curve. The graph of cumulative data versus a related variable's cumulative data is a straight line when the relationship between the variables is a fixed ratio [61]. Modifications in the variable's relationship trigger break in such variables' double-mass curve. These modifications may be due to alterations in the data collection technique or physical changes affecting the relationship [62].

\subsection{Model Setup}

Catchment, node, and conduit input are required to run the flood simulation using XPSWMM modeling software [14,63]. Peak flows were simulated to determine the hydrology and hydraulics of a drainage area model using rainfall data and variations of impermeable data, along with sub-catchment particular parameters [64]. Each catchment is subdivided into hydrologically similar sub-catchments. For each sub-catchment, the model needs specific parameters to define the flow of sub-catchment region, 
impermeable percentage, pervasive curve number (a soil permeability rating), and concentration time. Overall, this modeling process can be simplified in Figure 2.

The flood simulation model using XPSWMM in the Aur River catchment consists of several steps. The first step is input parameters are determined. Then, the Aur River catchment is divided into 81 sub-catchments. The main channels, which collect the surface runoff on sub-catchments, are defined into the model as conduits by using the topographical map. The Aur River catchment is sufficiently small so that the design rainfall is the same and is divided into areas with similar infiltration characteristics. Catchment inputs are required to provide information for the rainfall-runoff module. The catchment roughness applied in the calculation of the storage delay parameter is taken from the Manning, $n$ value for the sub-catchment with the infiltration information. Conduit refers to any conveyance components that carry water. In the Aur River catchment, two types of conduits were commonly used, which are drain and river. For rainfall input, Sek. Men. Raja Lumu (3014092) rainfall stations were chosen for the derivation of rainfall intensity duration curve (RIDF) and temporal pattern as they are located within the catchment area. The rainfall intensities and the temporal pattern will be used as input parameters in the model.

Hydrological modeling is used to estimate tributary sub-catchment flood hydrographs at various recurrence intervals as an input to the hydraulic model for each catchment area (Table A1). The model simulates natural mechanisms of rainfall-runoff and the hydraulic performance of drainage systems used for water resource management. It provides integrated flow and pollutant transport analysis in engineered and natural structures, including ponds, waterways, lakes, estuaries, and groundwater interactions $[3,36,65,66]$.

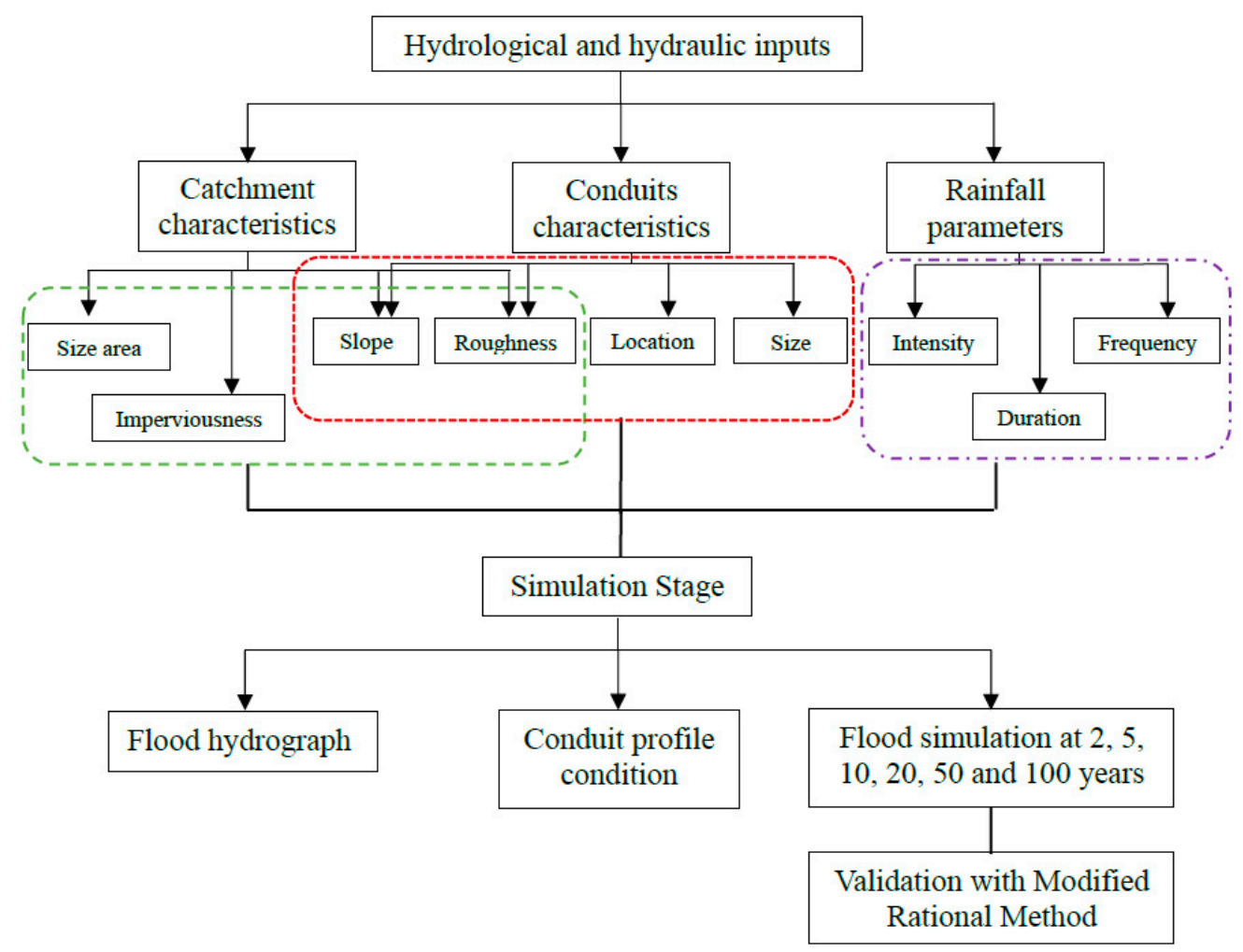

Figure 2. Modeling process using the XP Stormwater Management Model (XPSWMM).

Hydrological and hydraulic modeling was carried out to determine the performance and efficiency of significant drainage network in the study area. It has been found that there is no streamflow gauging station within the catchments to check and validate the flood estimation from the proposed method. Therefore, Hydrological Procedure No. 16 (HP16): Flood Estimation for Urban Areas in Peninsular Malaysia have been adapted for calibration purposes. The modeling part is carried out using XPSWMM, 
as this software is capable of carrying out modeling of the flood discharges within the drainage network of each catchment, giving the flood event details and the inflows. XPSWMM designs the hydrological and hydraulic elements of most stormwater management systems comprehensively [67]. It involves continuous simulation modeling capacities, various techniques for generating hydrographs, open channel mixtures and closed conduits, looped networks, storage nodes such as lakes, and multiple outages [66,68-71]. Finally, the peak discharge of flood simulation from XPSWMM was validated with a modified rational method for comparing the calculated peak discharge with the simulated peak discharge.

\section{Results}

Physical characteristics of the catchment are crucial for hydrological assessment [3]. From the topographic maps, boundaries of catchments are delineated. As well as the maximum and minimum elevations along with them, the central drainage systems are traced. For estimating runoff quantities, the difference in elevation within the catchment is used. Generally, the runoff coefficient for each catchment is calculated from the ground cover, topography, and form of the catchment area [11]. The catchment boundary area has been delineated based on the digital terrain model (DTM) generated by LiDAR data, IKONOS satellite imagery, and on-ground verification of actual drainage lines (Figure 3). These features are then utilized to establish nodes and links in the XPSWMM model of stormwater systems [71]. The terrain, or DTM, is utilized to process additional information, such as sub-catchment areas, surface slopes, and longest flow paths, required for the computation of parameters depending on the selected method for hydrological analysis [4,72]. Catchment delineation was developed during the development of Drainage Masterplan Study for the town of Klang. Nevertheless, verification was done based on the LiDAR elevation information and several site visits.

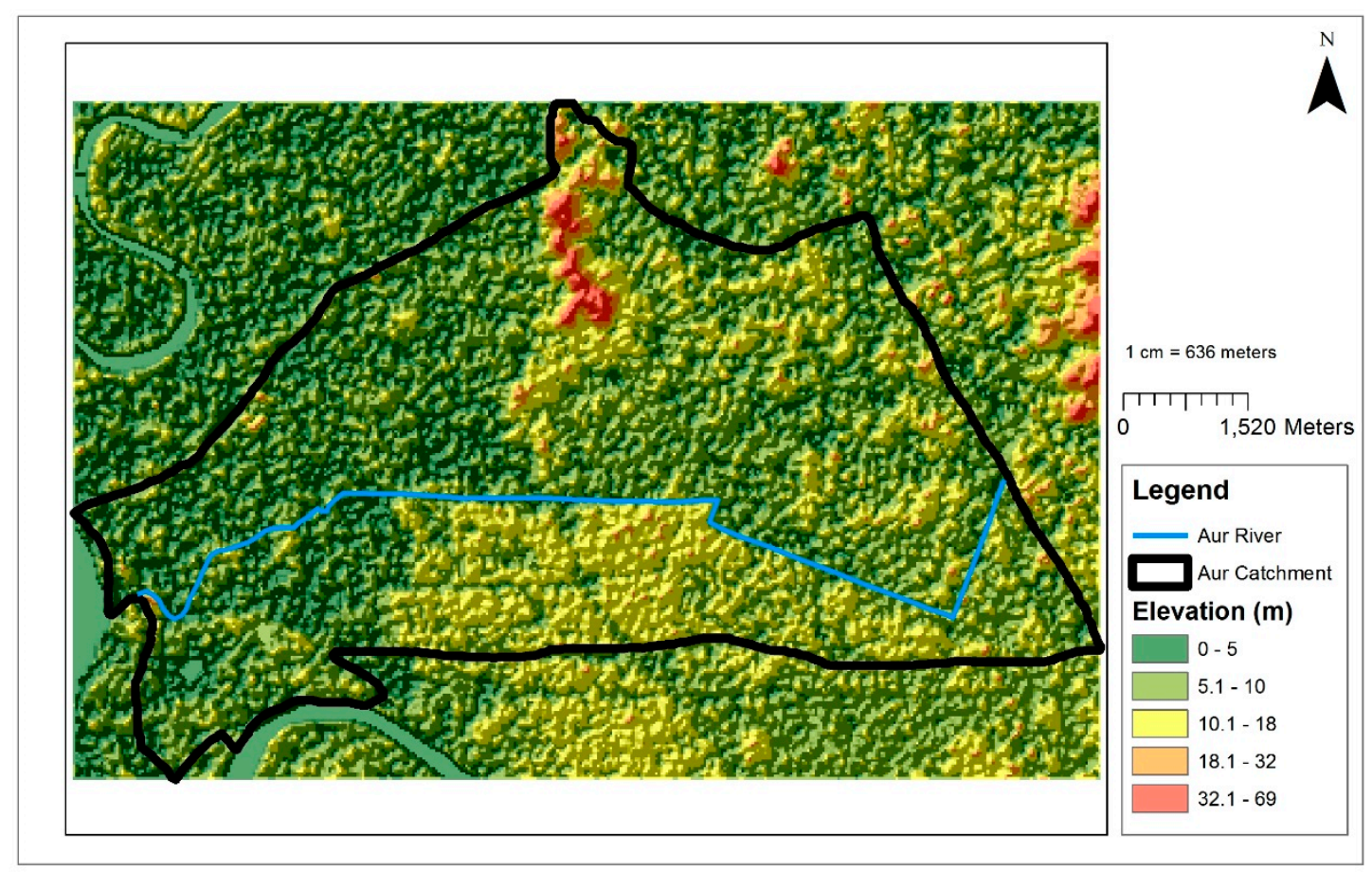

Figure 3. Elevation information from the LiDAR survey for the project area.

\subsection{Rainfall Time Series}

The daily recorded rainfall data from the year 2006 to 2014 are shown in Figure A1 for Sek. Men. Raja Lumu Station (St. 3013003). The highest daily rainfall recorded occurred on 30 March 2012, with a $195 \mathrm{~mm}$ rainfall depth. It is shown that the variation in the daily amount of rainfall is high at the beginning and end of each year, indicating that climate and monsoon affect the daily depth of rainfall. 
For the developed simulated model purpose, several different rainfall scenarios were achieved using the intensity-duration-frequency (IDF) curves, which were already developed for the study area.

The Gumbel's distribution analysis was done following Equations (1) to (3), and the results obtained are shown in Figure 4a. Gumbel distribution was compared using the Weibull plotting position to see if there are significant differences in the rainfall values. By using this curve, annual maximum daily rainfall values corresponding to any return period from 1- to 100-year can be predicted. A plot of return period for 2-, 5-, 10-, 20-, 25-, 50-, and 100-year versus annual maximum daily rainfall was plotted for Sek. Men. Raja Lumu Station, which is shown in Figure 4b.

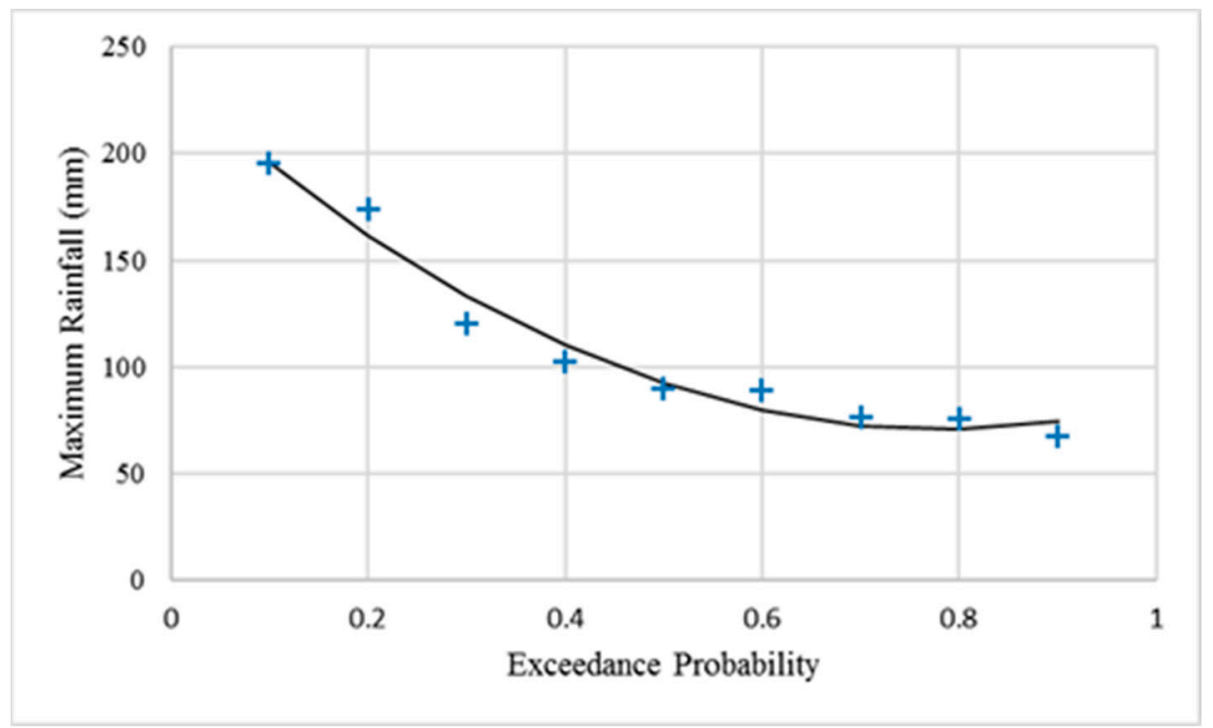

(a)

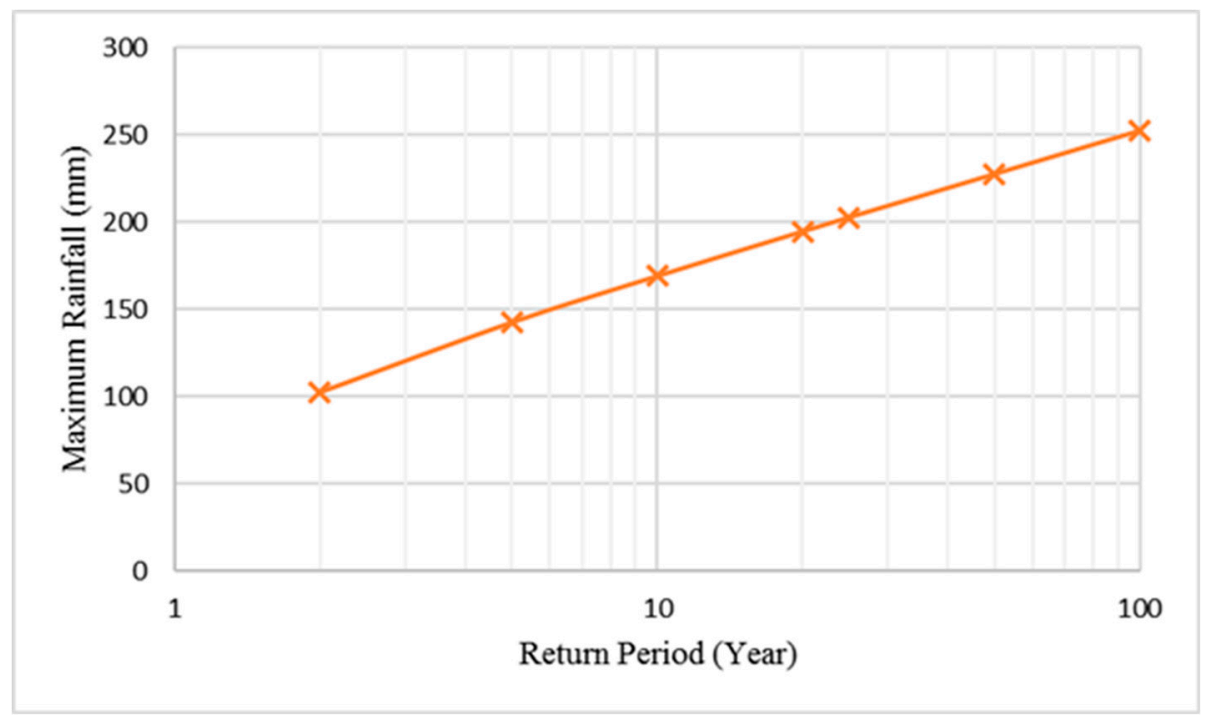

(b)

Figure 4. (a) The exceedance probability distribution and (b) rainfall frequency curve, for annual maximum daily rainfall for Sek. Men. Raja Lumu Station (St. 3013003).

From the Gumbel's distribution using return periods $(\mathrm{T})$ as shown in Figure $4 \mathrm{~b}$, the estimated annual maximum daily rainfall for 2-, 5-, 10-, 20-, 25-, 50-, and 100-year obtained are $102.7 \mathrm{~mm}, 142.7 \mathrm{~mm}$, $169.2 \mathrm{~mm}, 194.7 \mathrm{~mm}, 202.8 \mathrm{~mm}, 227.6 \mathrm{~mm}$, and $252.4 \mathrm{~mm}$, respectively. The annual maximum daily 
rainfall of the return period is useful for irrigation systems designing, reservoir designing, storm management, and water balance modeling [16,73].

Rainfall extreme events were conducted using rainfall data from St. 3014092 rainfall stations. Tables 3 and 4 indicate the rainfall intensities and depth that will be used as input parameters in the model. The IDF curve for Sek. Men. Raja Lumu (3014092) station is given in Figure 5, while Figure A2 in Appendix A presents the rainfall hyetograph of different durations-15, 30, 60, 180, 360, 720, and 1440 min intervals. Figure 6 shows the double mass curve for Sek. Men. Raja Lumu Station. Simulations were carried out using different model inputs (catchment, stormwater system, and rainfall). By combining different on, the model allows assessment of the stormwater system to identify issues and provide solutions. Results for simulated flow discharge are summarized in Table 5 for the study area with current land use.

Table 3. Estimated rainfall intensity (mm/hr) for Sek. Men. Raja Lumu Station (No. 3014092).

\begin{tabular}{ccccccccc}
\hline \multirow{2}{*}{ ARI (Year) } & \multicolumn{7}{c}{ Storm Duration (min) } \\
\cline { 2 - 9 } & $\mathbf{1 0}$ & $\mathbf{1 5}$ & $\mathbf{3 0}$ & $\mathbf{6 0}$ & $\mathbf{1 8 0}$ & $\mathbf{3 6 0}$ & $\mathbf{7 2 0}$ & $\mathbf{1 4 4 0}$ \\
\hline 2 & 135.0 & 119.0 & 92.4 & 64.0 & 30.0 & 17.0 & 9.0 & 4.8 \\
5 & 159.8 & 143.0 & 110.9 & 77.7 & 37.0 & 21.5 & 11.5 & 5.9 \\
10 & 174.0 & 158.0 & 123.1 & 87.9 & 44.0 & 25.4 & 13.6 & 7.1 \\
20 & 189.0 & 172.3 & 134.8 & 97.6 & 52.0 & 29.2 & 15.7 & 8.1 \\
50 & 203.5 & 187.2 & 150.0 & 110.2 & 58.0 & 34.1 & 18.4 & 9.5 \\
100 & 220.0 & 202.0 & 161.4 & 119.7 & 63.0 & 37.7 & 20.4 & 10.5 \\
\hline
\end{tabular}

Table 4. Estimated rainfall depth (mm) for Sek. Men. Raja Lumu Station (No. 3014092).

\begin{tabular}{ccccccccc}
\hline \multirow{2}{*}{ ARI (Year) } & \multicolumn{7}{c}{ Storm Duration (min) } \\
\cline { 2 - 9 } & $\mathbf{1 0}$ & $\mathbf{1 5}$ & $\mathbf{3 0}$ & $\mathbf{6 0}$ & $\mathbf{1 8 0}$ & $\mathbf{3 6 0}$ & $\mathbf{7 2 0}$ & $\mathbf{1 4 4 0}$ \\
\hline 2 & 23.2 & 32.7 & 46.2 & 62.4 & 84.0 & 93.3 & 99.3 & 102.7 \\
5 & 26.6 & 37.2 & 55.4 & 77.7 & 119.6 & 128.9 & 138.1 & 142.7 \\
10 & 28.9 & 40.2 & 61.5 & 87.9 & 143.3 & 152.5 & 163.8 & 169.2 \\
20 & 31.1 & 43.1 & 67.4 & 97.6 & 166.0 & 175.1 & 188.5 & 194.7 \\
50 & 33.9 & 46.8 & 75.0 & 110.2 & 195.3 & 204.4 & 220.4 & 227.6 \\
100 & 36.0 & 49.6 & 80.7 & 119.7 & 217.4 & 226.4 & 244.4 & 252.4 \\
\hline
\end{tabular}

Table 5. Flow discharge for the Aur River model.

\begin{tabular}{ccccccc}
\hline \multirow{2}{*}{ Storm Duration (min) } & \multicolumn{7}{c}{ ARI (Year) } \\
\cline { 2 - 7 } & $\mathbf{2}$ & $\mathbf{5}$ & $\mathbf{1 0}$ & $\mathbf{2 0}$ & $\mathbf{5 0}$ & $\mathbf{1 0 0}$ \\
\hline 15 & 85.250 & 97.678 & 105.962 & 113.971 & 124.189 & 131.922 \\
30 & 119.615 & 144.851 & 161.583 & 177.767 & 198.614 & 214.249 \\
60 & 161.851 & 203.543 & 231.337 & 257.770 & 292.104 & 317.992 \\
180 & 187.163 & 269.093 & 323.635 & 375.876 & 443.306 & 494.170 \\
360 & 163.058 & 226.727 & 268.917 & 309.306 & 361.659 & 400.962 \\
720 & 120.538 & 168.382 & 200.055 & 230.489 & 269.787 & 299.350 \\
1440 & 71.159 & 99.679 & 118.563 & 136.731 & 160.168 & 177.833 \\
\hline
\end{tabular}




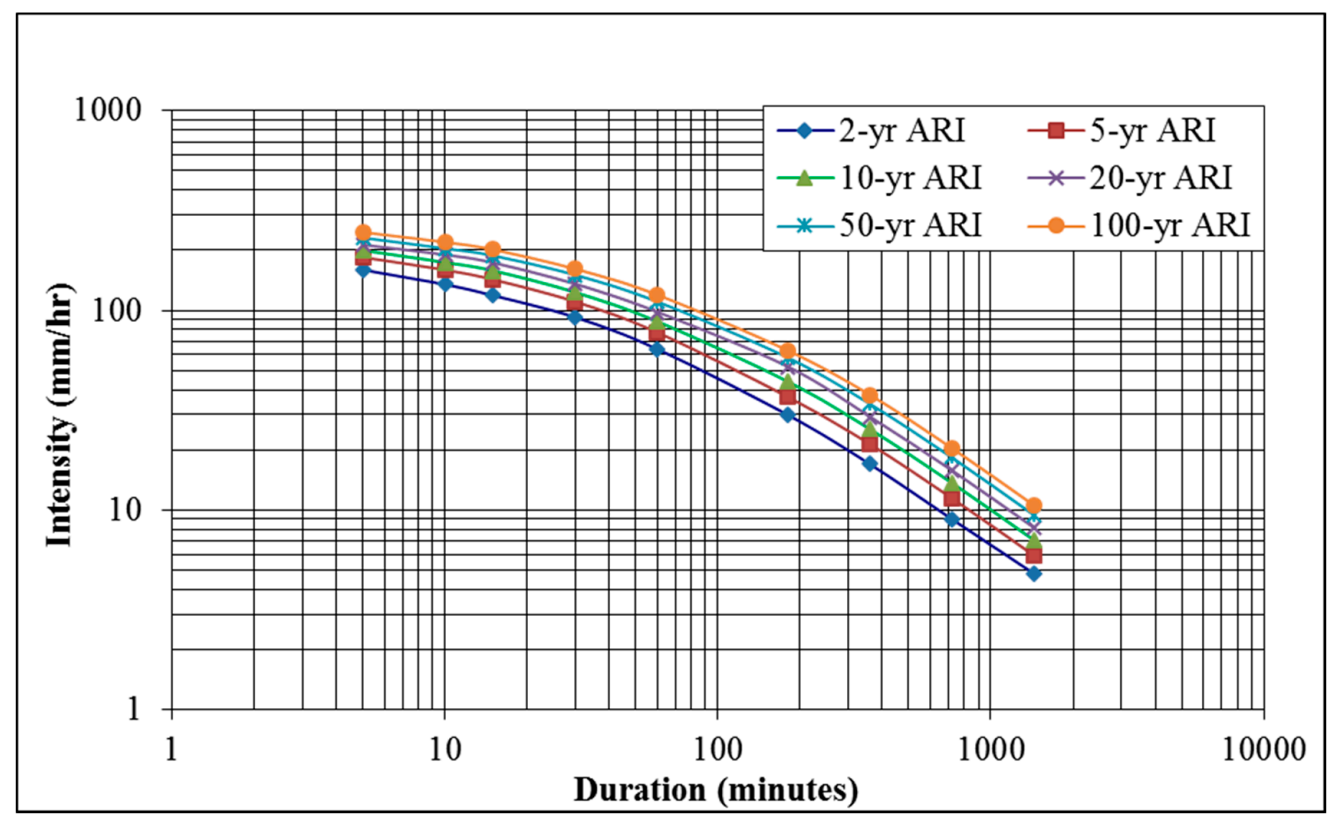

Figure 5. Rainfall intensity duration frequency curve for Sek. Men. Raja Lumu Station (No. 3014092) from 2006 to 2014.

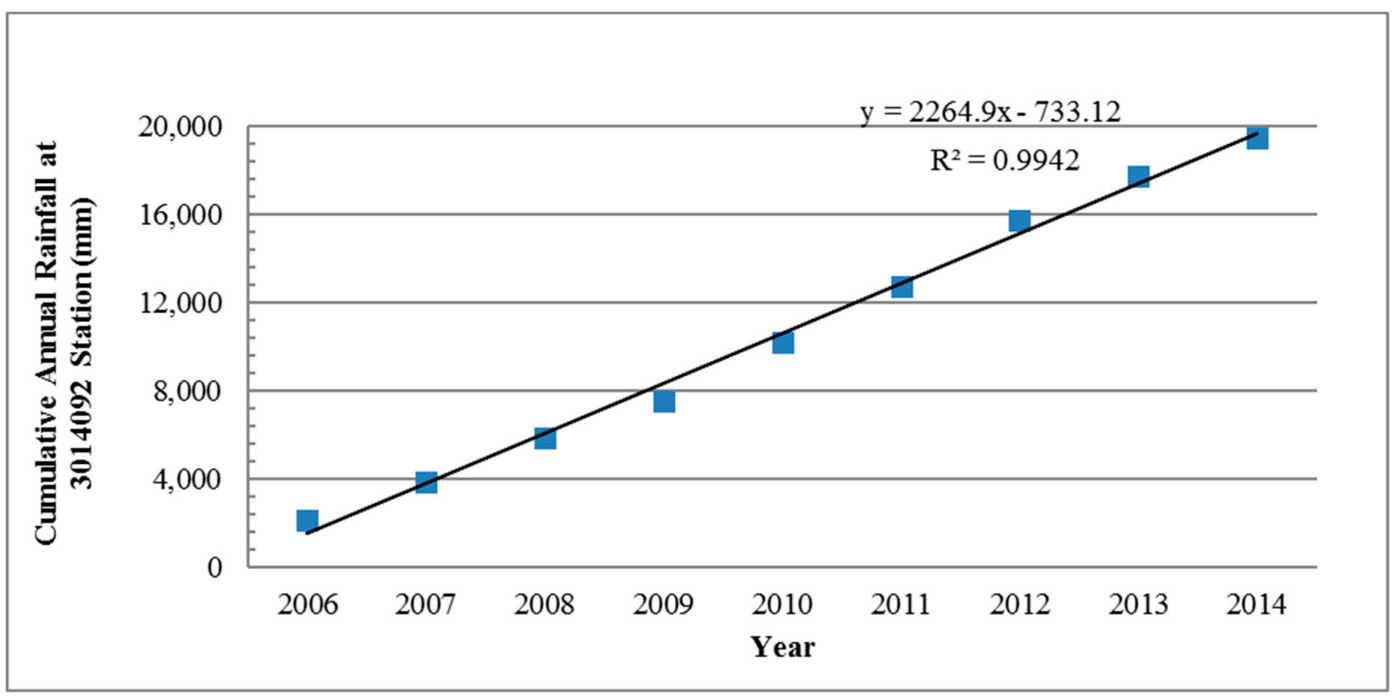

Figure 6. The double mass curve for Sek. Men. Raja Lumu Station (No. 3014092).

\subsection{Design Flood Hydrograph}

The simulated flood hydrograph was produced for different ARIs, focusing more on the maximum critical duration, which is $180 \mathrm{~min}$ for the Aur River outlet. This is the total design flood hydrographs from each sub-catchment for the location. Figure 7 shows the design flood hydrograph for existing land use. 


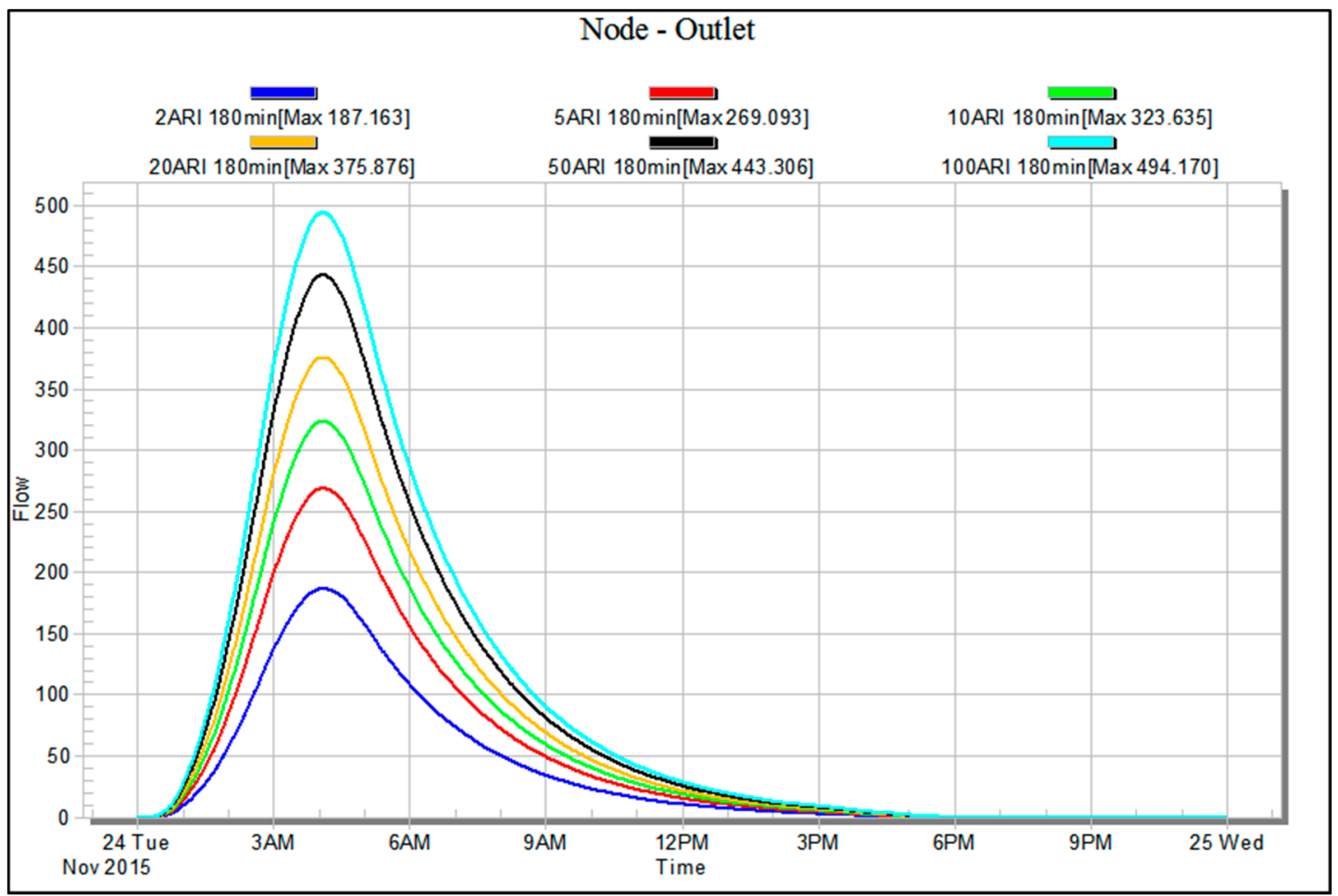

Figure 7. Design flood hydrographs for the Aur River outlet.

\subsection{Model Validation}

The Aur River catchment has no streamflow station available for calibration purposes. Therefore, to check the validity of the model, the comparison of peak discharge has been made using the modified rational method. The modified rational method is the most frequently used technique for runoff peak estimation in Malaysia and many parts of the world [52,74]. An evaluation has been done for the Aur River outlet as tabulated in Table 6 for the correlations of the peak discharge for existing land use using XPSWMM and modified rational method. The peak discharges of the Aur River catchment for 2-, 5-, 10-, 20-, 50-, and 100-year ARIs are calculated using a modified rational method.

Table 6. Comparison of peak discharge for the Aur River outlet.

\begin{tabular}{|c|c|c|}
\hline \multirow{2}{*}{ Method } & \multicolumn{2}{|c|}{ Existing Land Use } \\
\hline & XPSWMM & Modified Rational Method \\
\hline ARI & \multicolumn{2}{|c|}{ Peak Discharge $\left(\mathrm{m}^{3} / \mathrm{s}\right)$} \\
\hline 2 & 187.163 & 234.08 \\
\hline 5 & 269.093 & 282.70 \\
\hline 10 & 323.635 & 315.11 \\
\hline 20 & 375.876 & 329.12 \\
\hline 50 & 443.306 & 371.13 \\
\hline 100 & 494.170 & 441.16 \\
\hline
\end{tabular}

\section{Discussion}

\subsection{Hydraulic Simulation}

In this study, the hydrodynamic model also incorporates XPSWMM, a 2D hydrological model in most stormwater management systems' and hydraulic elements based on cross-section data acquired [21]. The hydraulic model was developed based on the preliminary engineering survey data, LiDAR data, and previously existing data based on the Masterplan that has been incorporated in this 
simulation. The hydraulic analysis is a tool for the preliminary design of drainage infrastructures to address flooding problems in the sub-catchments under the design storm. Hydraulic modeling is carried out using the existing drainage network with the current land use and drainage infrastructure. Through analysis conducted using XPSWMM software, a total of 24 nodes were analyzed based on different return periods. The return period examined in this study was 2-, 5-, and 10-year. This catchment has three existing detention ponds: two at the upstream part of the basin (Taman Botani and Bandar Puteri), and another one at the downstream part of the basin (near Jalan Banting Pandamaran). The main drains and secondary drains contribute from a few places, namely Jalan Raja Nong, Jalan Kebun Nenas, Taman Sentosa, Jalan Dato Dagang, and other adjacent areas, and flow into the detention ponds before being discharged into the Aur River and finally into the Klang River. Figure 8a-d shows the location of the conduit profile condition for each node based on XPSWMM in the Aur River catchment.

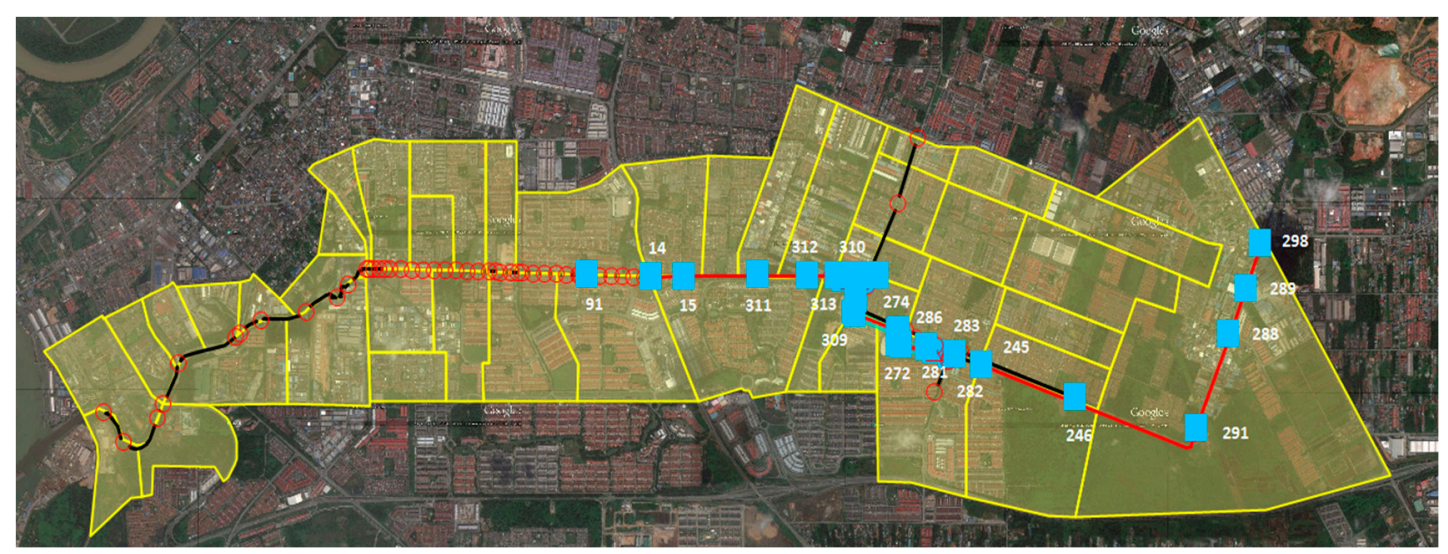

(a)

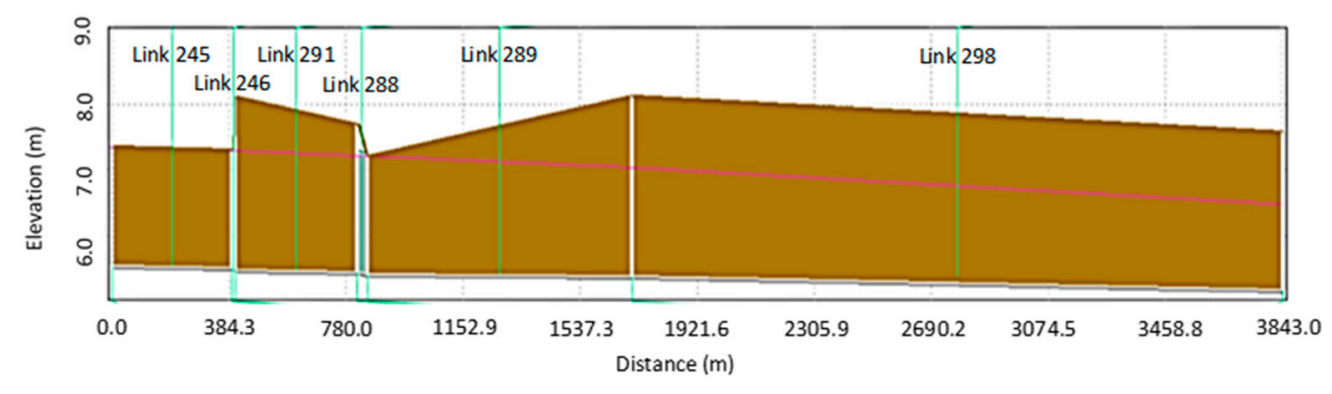

(b)

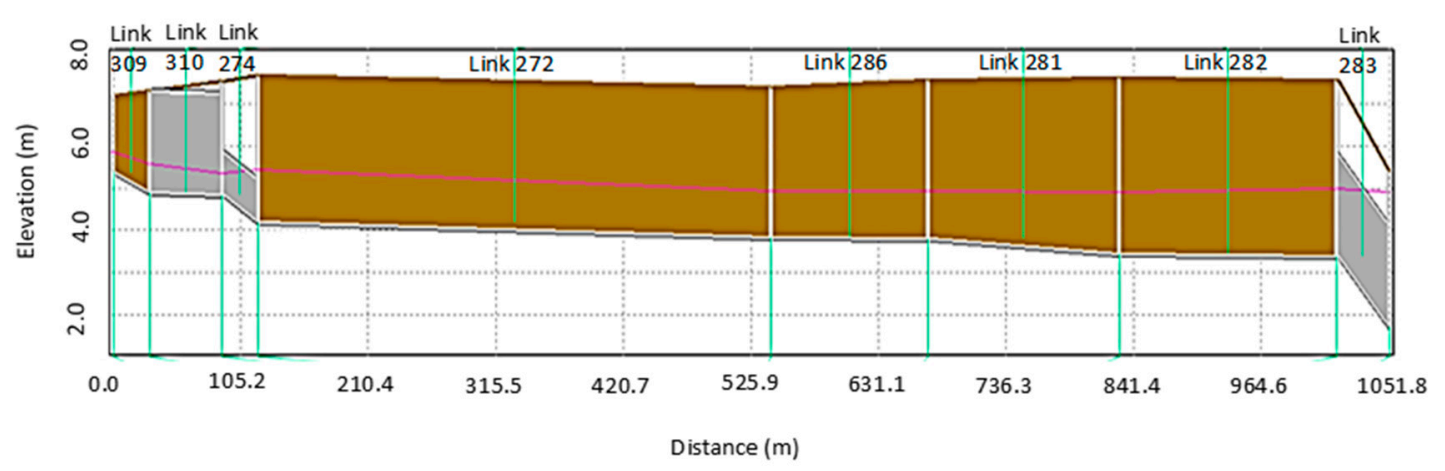

(c)

Figure 8. Cont. 


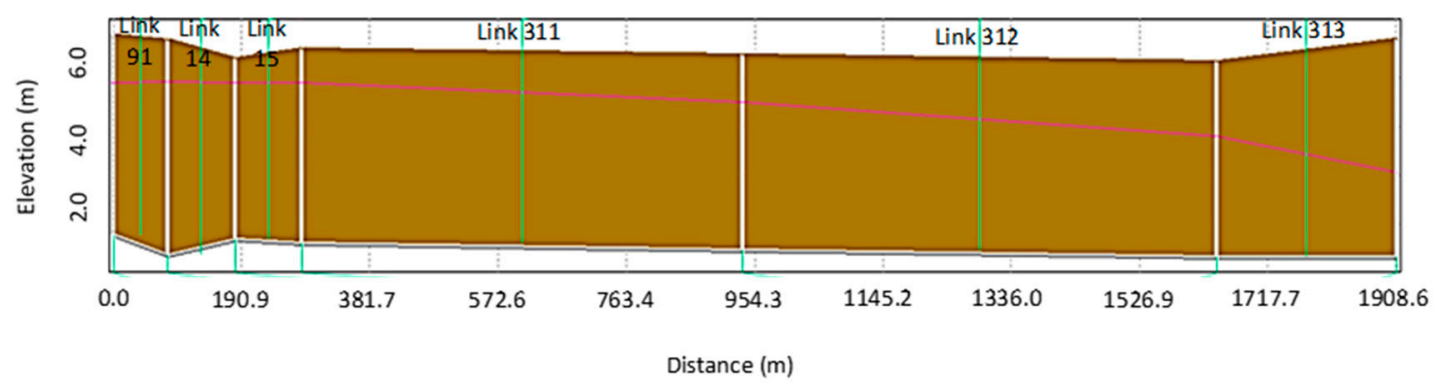

(d)

Figure 8. (a) Location of conduit profile condition for each node, existing, and proposed conduit profile condition: (b) from Link 245 to Link 298, (c) from Link 309 to Link 283, and (d) from Link 91 to Link 313.

\subsection{Design Storm Return Periods}

The expansion and development of any projects in the Aur River catchment will induce hydrological cycle distortion and change watershed systems characteristics such as increased runoff and a decline in groundwater due to increasing the impermeable surface. As a result, it has emerged as a significant cause of damage to the integrity of the basin, and rainfall-runoff changes were identified using XPSWMM. The runoff reduction effect was predicted to maintain the state of the water condition before and after development.

Urbanization is expected to spread from this focal point. Therefore, it is recommended that the adopted storm design criteria shall be uniformly used throughout the study area reflective of the state of development. MSMA has recommended that the 10-year ARI storm be used for the minor drainage and 100-year ARI for the major drainage [75]. It is, therefore, the 10-year ARI is used in the design of the drainage systems in each of the drainage sub-catchments of the study area. However, 100-year ARI designed drains will be provided as a check to the recommended 10-year ARI design drains. Meanwhile, the analysis for the drainage systems shall be for 100-year ARI to investigate the catchment behavior during extreme events. Detailed hydraulic modeling was carried out to evaluate flood profile under the existing and future conditions for 2-, 5-, 10-, 50- and 100-year ARIs, focusing on the Aur River catchment area. The main factor of flooding issue is due to the existing condition of the main drains at Jalan Raja Nong, Jalan Seruling 69, Jalan Kebun Nenas, and Jalan Dato Dagang 6 that are mostly insufficient to cater to the flow, causing the water level rise along the road during heavy storms. Besides that, the two detention ponds at the upstream part of the catchment-Taman Puteri and Bandar Botani-are not functioning well and cater only for the incoming residential catchment. The capacity of Aur River itself is insufficient to cater to the 50-year ARI, as the incoming flow from the upstream catchment is too big. In general, if the drainage system is not in proper condition, flooding may occur due to overflow from the drain to the surrounding area. Figure $9 \mathrm{a}, \mathrm{b}$ shows the location of flood for the 50-year ARI and 100-year ARI storm events, respectively, based on the XPSWMM simulation. The water gets overflow from drain during the peak rainfall period. Simulation is done, and the longitudinal profile of the drain of all sub-catchments is similarly analyzed. After simulation using XPSWMM, it is observed that the water overflows during peak runoff. The existing drain is found not sufficient to hold the peak runoff during the rainy days. In preventing the overflow water from drainage, the necessity of increasing the drain size is observed. At a certain depth, the longitudinal profile of the drain seems to be secure. Similarly, all drainage networks are analyzed after the XPSWMM simulation. 


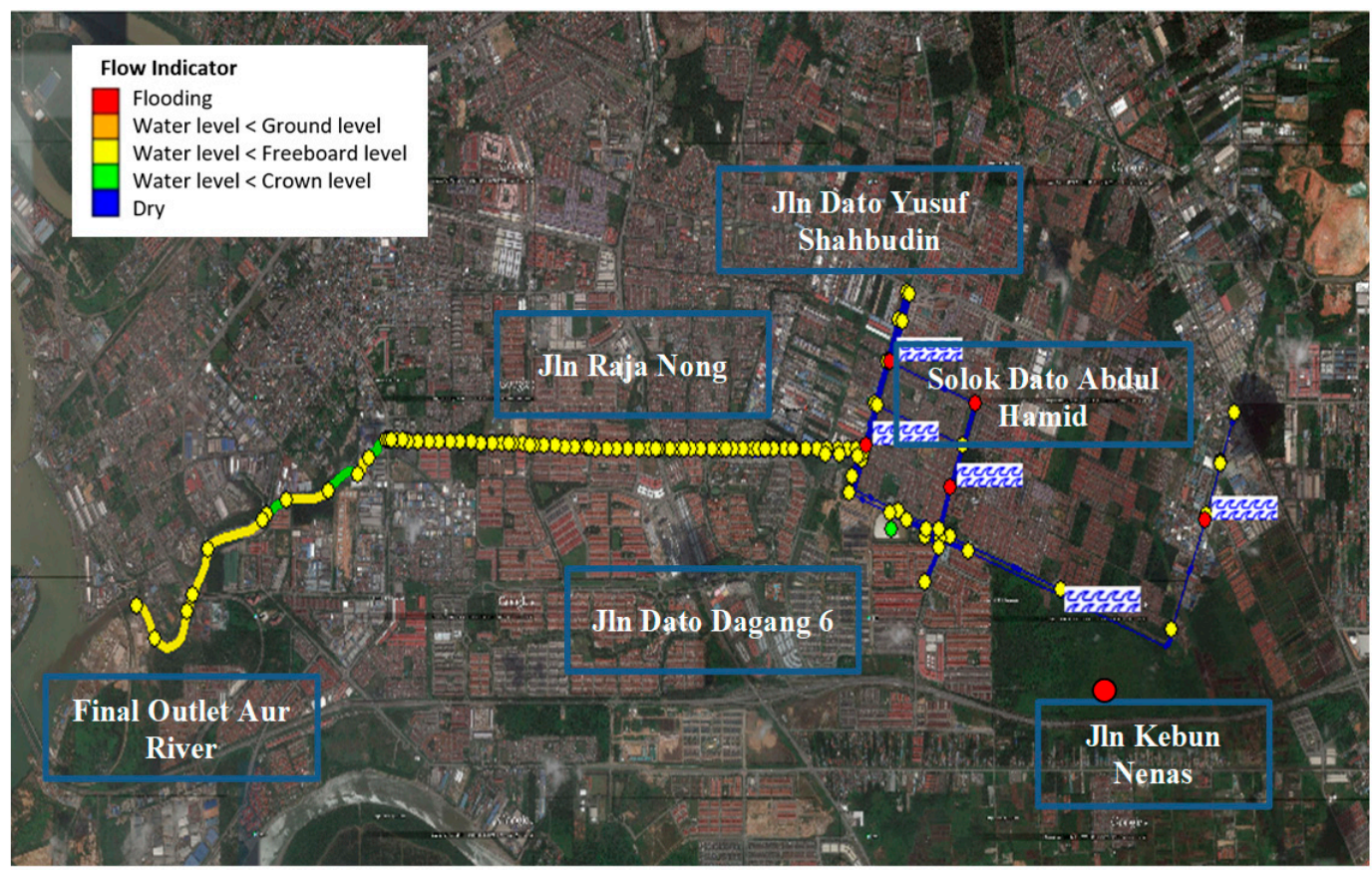

(a)

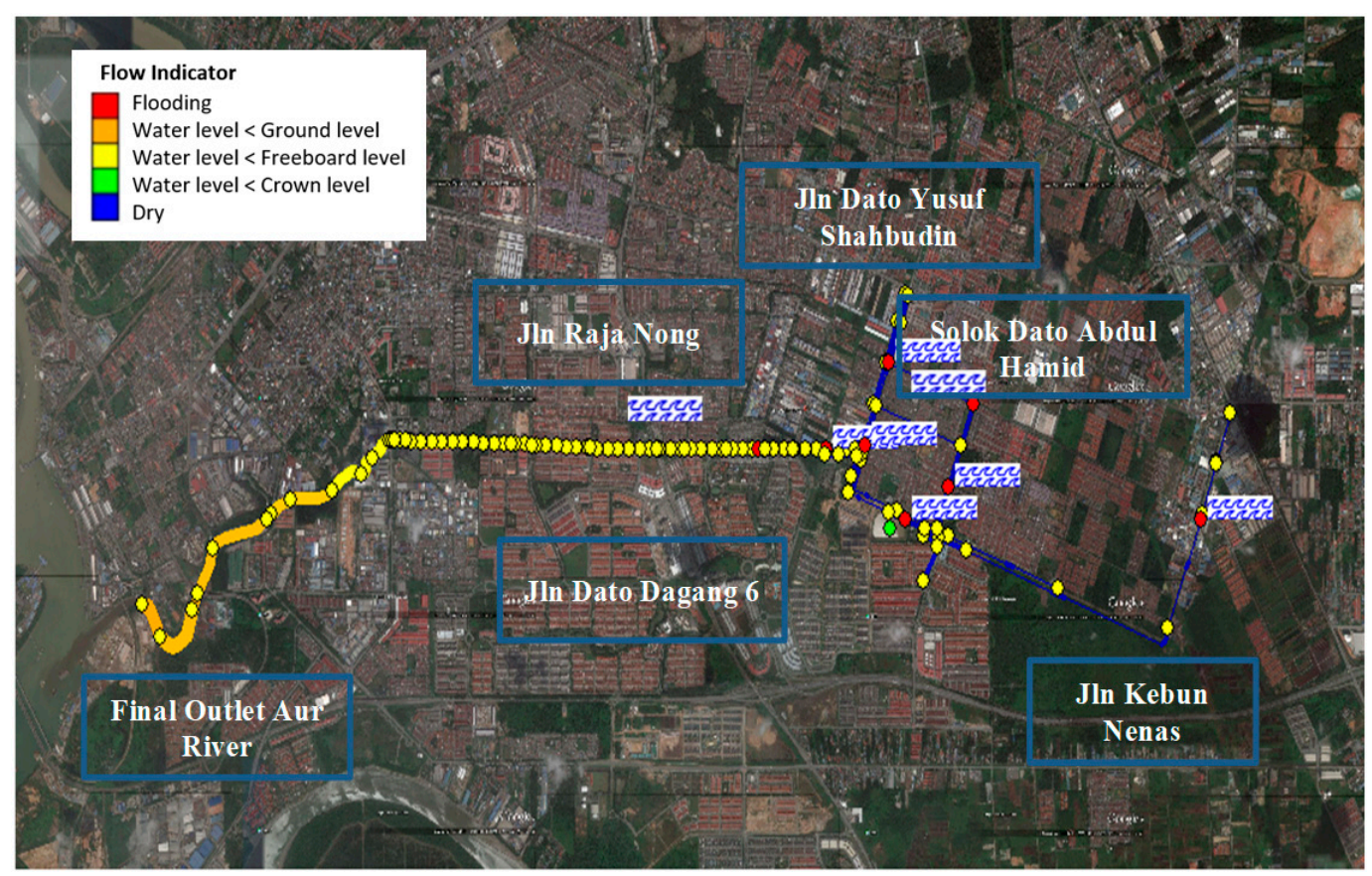

(b)

Figure 9. (a) Location of flood simulation for 50-year ARI; (b) Location of flood simulation for 100-year ARI.

This research relates to flood simulation analysis by taking into consideration the hydrological and hydraulic models and the impact of urbanization. Climate effects and meteorological conditions are very critical for flood events, which require a detailed understanding by improving the regimes of atmospheric circulation and climate models. Therefore, comprehensive models stand out in the investigation of meteorological factors and climate effects on the floods. Besides, the analysis carried out shows that the inefficiency of the drainage system will cause flooding. If the existing drainage 
system is inefficient and cannot cater to high rainfall events, a new initiative needs to be implemented. The presence of thick sediments will undermine the underlying condition of the drainage system. Also, sediment will cause the water velocity to slow down, in addition, to reduce the capacity of water flow downstream, which in turn will lead to overflow of the drainage system during heavy rainfall [76]. As the study area is near the river, this will lead to a faster sediment deposition process, and more sediment will be found in the area. Another factor that causes sediment deposition at the base of the drainage is erosion by the river or drainage system [77]. This is because there is an overflow of water that exceeds the drainage depth in some nodes. In preventing flooding that will affect traffic and the surrounding community, maintenance and deepening of the drainage should be undertaken. In addition, a new retention system should be constructed at the upstream basin so that the running water and rain can be collected there before it is released into the major drainage system.

Floods that occur instantaneously are caused by extreme volumes of water flowing suddenly and rapidly, covering large areas. Thus, floods are challenging to predict instantaneously because of the lack of knowledge regarding the behavior of the flood and the water quantity. Urban flood simulation was conducted in the affected area to obtain surface runoff in order to minimize the damage caused by floods. Based on the flood simulation, we can simulate how much land will be occupied by water for the different return periods. Despite this fact, and adopting a more careful strategy for friction modeling, the method can simulate the dynamics of the flood on the catchment surface in a fast and efficient way, and it can, therefore, be used for estimating rainfall in the ungauged area.

\section{Conclusions}

The occurrences of the flash flood were simulated using the XPSWMM model of the Aur River catchment based on the characteristics of the sub-catchment and storm sewer conduits. The flash flood events were simulated with a specific return period of rainfall, and the findings demonstrate that the study area will have no flooding with the 1-year rainfall return period, but the study area will be inundated with 2-, 5-, 10-, and 20-year rainfall return period. Since the frequency and intensity of rainfall events increases significantly, the capacity of the current drainage system in Aur River catchment will not be able to accommodate the excess rainfall. External factors, such as climate change, have brought an unprecedented challenge for drainage management for flood mitigation. From this study, the peak flow was predicted using XPSWMM software. The vicinity of the study area is located at the downstream of the Langat River basin and is surrounded by residential areas and municipal areas. In general, a flash flood is likely to occur in this area, as the depth of drainage is inefficient to accommodate high rainfall. The difference in water depth through the drainage affects the depth of the drainage. The flood simulations using existing and future land use also pose an increased challenge to floodplain management in the downstream of the Aur River catchment.

There are some areas where the depth of the drainage is unable to accommodate a high amount of water that occurs at a 50-year return period; there are at least six areas that will be flooded with water from the drainage. Therefore, it is proposed to increase the optimum depth of the drainage system. This profound work has to be done to prevent flood events that often disrupt the life of the local community. Also, researchers are encouraged to use GIS to facilitate map creation, which saves time and provides consistent geometric data of the study area. This study has not considered the presence of bridges that inevitably affect the flow regime. Therefore, for future studies, it is necessary to find the existence of bridges throughout the study area. In conclusion, XPSWMM can determine the height of peak flow rates based on rainfall data in a field.

In this study, we propose a methodology for comprehensively assessing urban flood simulation based on hydrologic-hydraulic modeling, scenario development and simulation, and multicriteria analysis of scenarios. The methodology was applied to an urban catchment and demonstrated the efficiency and transparency in presenting the simulation for floods in the characteristics of a catchment. The flood simulation can contribute to flooding disaster risk reduction efforts in an urban area. Understanding the meteorological and hydrological characteristics of this event is essential as a 
lesson learned for future flood disaster mitigation. Further, there is a growing need for stormwater management strategies to reduce urban flood risk. This research adopted an interdisciplinary and relatively holistic approach for flood simulation, consisting of hydrological and hydraulic aspects. As a result, research approaches and findings are useful for a wide range of stakeholders. The quantification of the climate change impact on the drainage system helps managers to predict oncoming and future problems. From this flood simulation, the findings help design efficient measures to retrofit existing drainage systems in advance to make them withstand future precipitation and provide the desired level of service. The proposed models of stormwater will help us to understand the context as well as specific solutions to be adopted.

Author Contributions: Conceptualization, all authors; data curation, S.F.M.R. and A.Z.I.; methodology, H.H.H., S.F.M.R., and A.Z.I.; validation, all authors; formal analysis, S.F.M.R. and A.Z.I.; writing-original draft preparation, H.H.H.; writing—review and editing, H.H.H., S.F.M.R., and A.Z.I.; visualization, all authors.

Funding: This work was partially supported by the Ministry of Education Malaysia research grant FRGS/1/2018/ TK01/UKM/02/2 and is gratefully acknowledged.

Acknowledgments: We would like to acknowledge the Department of Irrigation and Drainage, Malaysia for the rainfall, and Klang Municipal Council for the survey data used for this work. Also, ZHL Sdn. Bhd. in supporting this project to be completed successfully.

Conflicts of Interest: The authors declare no conflict of interest.

\section{Appendix A}

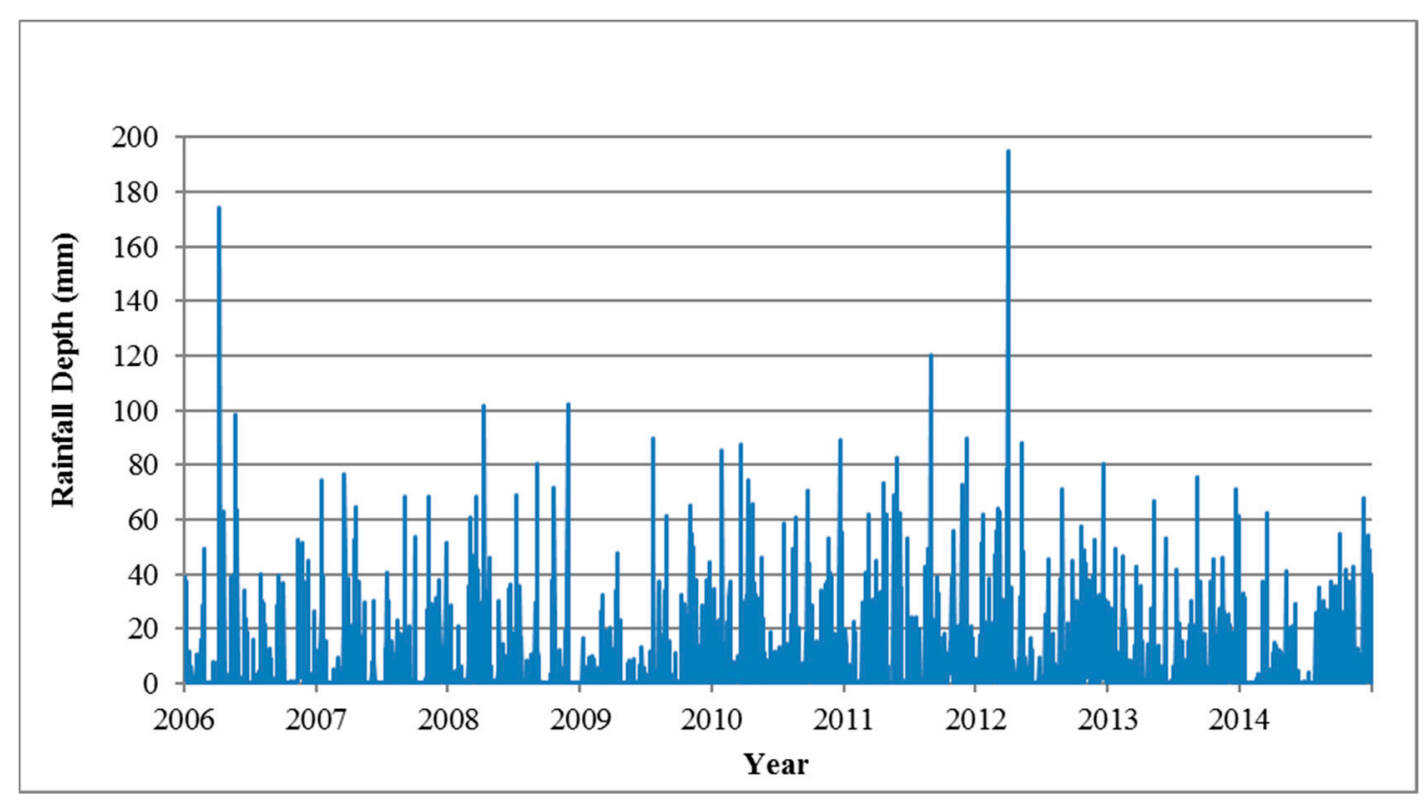

Figure A1. Daily rainfall time series for Sek. Men. Raja Lumu Station (No. 3014092).

Table A1. Hydrology input parameters for XP-SWMM (overall catchment).

\begin{tabular}{|c|c|c|c|c|}
\hline \multirow{2}{*}{$\begin{array}{l}\text { Overall } \\
\text { Catchment }\end{array}$} & \multirow{2}{*}{ Area (Ha) } & \multicolumn{2}{|c|}{ Imperviousness (\%) } & \multirow{2}{*}{$\begin{array}{c}\text { Catchment Slope } \\
(\%)\end{array}$} \\
\hline & & Existing & Future & \\
\hline Sg. Aur & 3978.564 & 71 & 89 & 0.0016 \\
\hline
\end{tabular}


Table A2. Hydrology input parameters for XP-SWMM (sub-catchment).

\begin{tabular}{|c|c|c|c|c|}
\hline \multirow{2}{*}{ Sub-Catchment ID } & \multirow{2}{*}{ Area (Ha) } & \multicolumn{2}{|c|}{ Imperviousness (\%) } & \multirow{2}{*}{ Catchment Slope (\%) } \\
\hline & & Existing & Future & \\
\hline SA01 & 33.105 & 40 & 90 & 0.005 \\
\hline SA02 & 55.954 & 85 & 100 & 0.004 \\
\hline SA03 & 53.378 & 35 & 75 & 0.002 \\
\hline SA04 & 33.907 & 90 & 100 & 0.003 \\
\hline SA05 & 33.827 & 95 & 100 & 0.002 \\
\hline SA06 & 8.283 & 90 & 100 & 0.002 \\
\hline SA07 & 9.388 & 40 & 80 & 0.008 \\
\hline SA08 & 4.846 & 40 & 75 & 0.011 \\
\hline SA09 & 21.136 & 80 & 100 & 0.007 \\
\hline SA10 & 10.478 & 70 & 95 & 0.006 \\
\hline SA11 & 72.29 & 60 & 80 & 0.004 \\
\hline SA12 & 46.718 & 65 & 90 & 0.005 \\
\hline SA13 & 18.569 & 70 & 90 & 0.032 \\
\hline SA14 & 36.243 & 98 & 100 & 0.002 \\
\hline SA15 & 22.95 & 60 & 90 & 0.011 \\
\hline SA16 & 57.21 & 80 & 90 & 0.018 \\
\hline SA17 & 45.435 & 55 & 75 & 0.015 \\
\hline SA18 & 85.214 & 55 & 80 & 0.067 \\
\hline SA19 & 25.628 & 60 & 75 & 0.006 \\
\hline SA20 & 11.013 & 100 & 100 & 0.003 \\
\hline SA21 & 17.223 & 98 & 100 & 0.004 \\
\hline SA22 & 19.21 & 20 & 80 & 0.007 \\
\hline SA23 & 13.495 & 85 & 100 & 0.007 \\
\hline SA24 & 21.926 & 40 & 75 & 0.009 \\
\hline SA25 & 66.395 & 90 & 100 & 0.018 \\
\hline SA26 & 31.542 & 35 & 70 & 0.003 \\
\hline SA27 & 30.237 & 100 & 100 & 0.004 \\
\hline SA28 & 16.67 & 95 & 100 & 0.005 \\
\hline SA29 & 11.803 & 80 & 95 & 0.007 \\
\hline SA30 & 18.323 & 65 & 85 & 0.024 \\
\hline SA31 & 14.025 & 80 & 95 & 0.013 \\
\hline SA32 & 33.429 & 95 & 100 & 0.005 \\
\hline SA33 & 45.194 & 60 & 85 & 0.004 \\
\hline SA34 & 41.748 & 85 & 100 & 0.007 \\
\hline SA35 & 27.942 & 85 & 100 & 0.002 \\
\hline SA36 & 66.289 & 80 & 95 & 0.004 \\
\hline SA37 & 26.551 & 95 & 100 & 0.003 \\
\hline SA38 & 32.754 & 80 & 95 & 0.008 \\
\hline SA39 & 49.732 & 85 & 98 & 0.007 \\
\hline SA40 & 24.251 & 80 & 95 & 0.009 \\
\hline SA41 & 49.191 & 60 & 80 & 0.006 \\
\hline SA42 & 198.486 & 70 & 95 & 0.003 \\
\hline SA43 & 33.258 & 90 & 100 & 0.022 \\
\hline SA44 & 37.574 & 70 & 90 & 0.005 \\
\hline SA45 & 30.031 & 80 & 100 & 0.005 \\
\hline SA46 & 81.824 & 85 & 95 & 0.002 \\
\hline SA47 & 77.027 & 75 & 95 & 0.005 \\
\hline SA48 & 102.55 & 85 & 100 & 0.004 \\
\hline SA49 & 86.292 & 60 & 80 & 0.011 \\
\hline SA50 & 77.065 & 98 & 100 & 0.022 \\
\hline SA51 & 51.475 & 90 & 100 & 0.011 \\
\hline SA52 & 11.533 & 95 & 100 & 0.004 \\
\hline SA53 & 118.022 & 75 & 88 & 0.008 \\
\hline SA54 & 28.24 & 60 & 90 & 0.005 \\
\hline SA55 & 30.26 & 98 & 100 & 0.009 \\
\hline
\end{tabular}


Table A2. Cont.

\begin{tabular}{ccccc}
\hline \multirow{2}{*}{ Sub-Catchment ID } & Area (Ha) & \multicolumn{2}{c}{ Imperviousness (\%) } & \multirow{2}{*}{ Catchment Slope (\%) } \\
\cline { 2 - 4 } & & Existing & Future & \\
\hline SA56 & 35.623 & 95 & 100 & 0.003 \\
SA57 & 6.902 & 70 & 95 & 0.006 \\
SA58 & 63.358 & 80 & 100 & 0.001 \\
SA59 & 71.961 & 80 & 100 & 0.006 \\
SA60 & 21.672 & 85 & 100 & 0.003 \\
SA61 & 16.508 & 75 & 95 & 0.009 \\
SA62 & 42.69 & 90 & 100 & 0.002 \\
SA63 & 11.824 & 98 & 100 & 0.004 \\
SA64 & 15.694 & 95 & 100 & 0.002 \\
SA65 & 16.858 & 85 & 95 & 0.002 \\
SA66 & 62.317 & 70 & 90 & 0.002 \\
SA67 & 49.262 & 90 & 100 & 0.003 \\
SA68 & 49.637 & 70 & 90 & 0.002 \\
SA69 & 102.365 & 60 & 80 & 0.009 \\
SA70 & 54.904 & 75 & 90 & 0.003 \\
SA71 & 87.197 & 60 & 80 & 0.004 \\
SA72 & 36.797 & 90 & 100 & 0.007 \\
SA73 & 39.607 & 90 & 100 & 0.003 \\
SA74 & 113.167 & 40 & 80 & 0.01 \\
SA75 & 34.128 & 85 & 95 & 0.005 \\
SA76 & 41.928 & 95 & 100 & 0.005 \\
SA77 & 77.76 & 65 & 85 & 0.004 \\
SA78 & 31.242 & 40 & 80 & 0.004 \\
SA79 & 35.088 & 60 & 80 & 0.004 \\
SA80 & 16.561 & 95 & 100 & 0.004 \\
SA81 & 494.543 & 55 & 85 & 0.007 \\
\hline
\end{tabular}

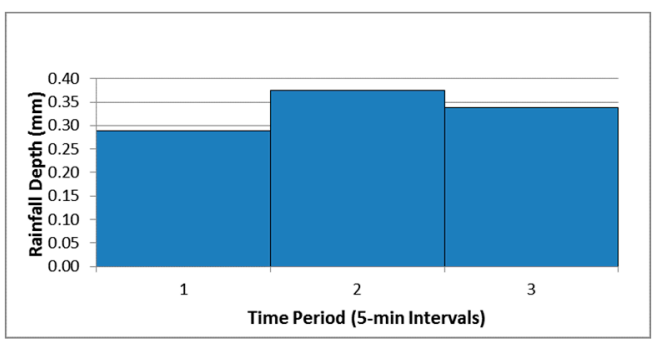

(a)

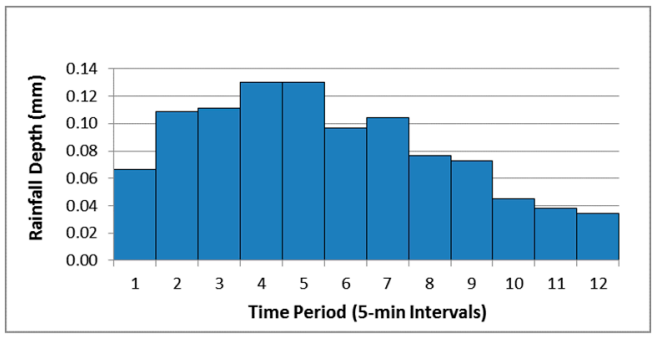

(c)

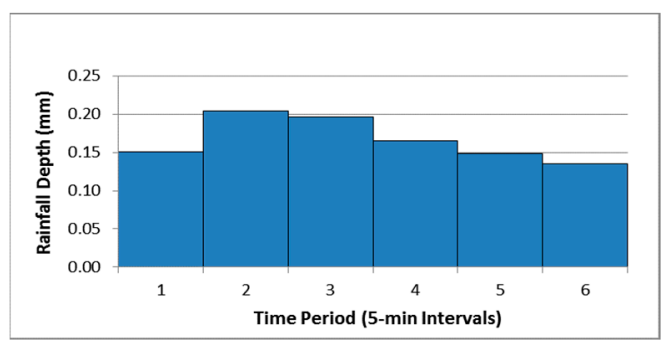

(b)

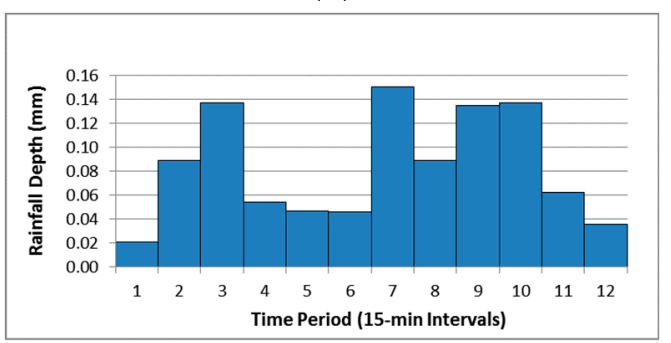

(d)

Figure A2. Cont. 


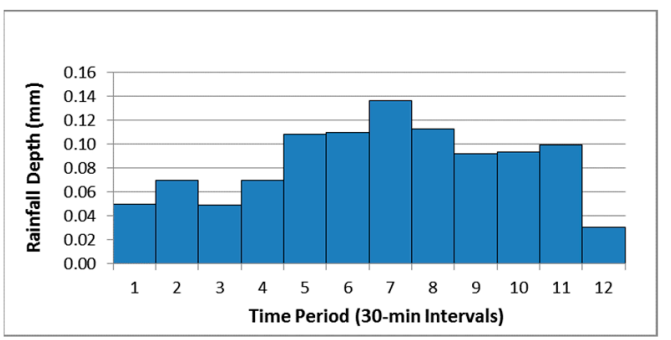

(e)

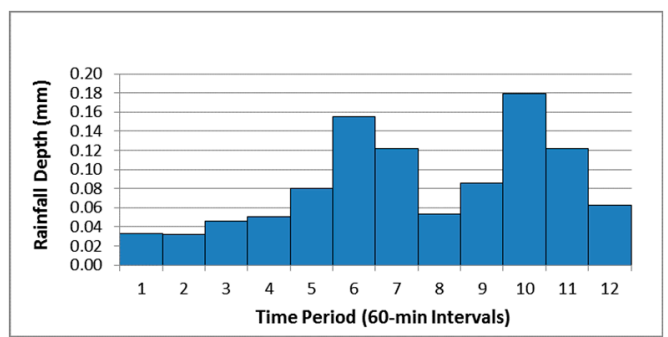

(f)

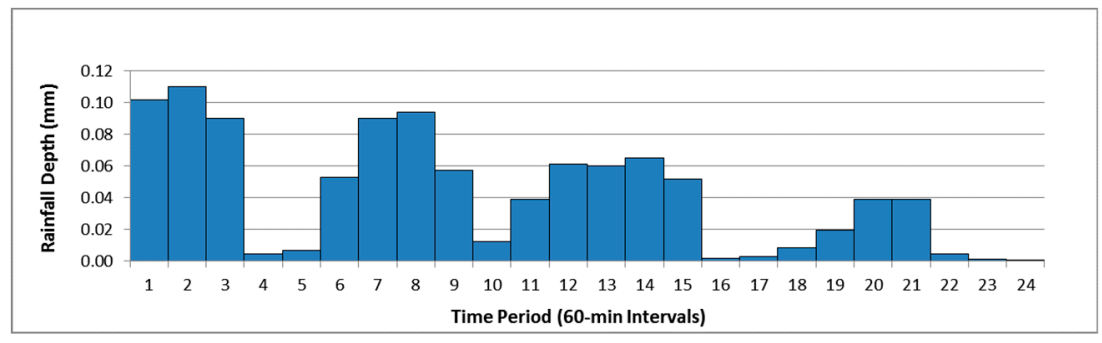

(g)

Figure A2. Rainfall hyetograph for Sek. Men. Raja Lumu Station. (a) $15 \mathrm{~min}$, (b) $30 \mathrm{~min}$, (c) $60 \mathrm{~min}$, (d) $180 \mathrm{~min}$, (e) $360 \mathrm{~min}$, (f) $720 \mathrm{~min}$, and (g) $1440 \mathrm{~min}$ durations.

\section{References}

1. Ozdemir, H.; Sampson, C.C.; De Almeida, G.A.M.; Bates, P.D. Evaluating scale and roughness effects in urban flood modelling using terrestrial LIDAR data. Hydrol. Earth Syst. Sci. 2013, 17, 4015-4030. [CrossRef]

2. Tingsanchali, T. Urban flood disaster management. Procedia Eng. 2012, 32, 25-37. [CrossRef]

3. Berndtsson, R.; Becker, P.; Persson, A.; Aspegren, H.; Haghighatafshar, S.; Jönsson, K.; Larsson, R.; Mobini, S.; Mottaghi, M.; Nilsson, J.; et al. Drivers of changing urban flood risk: A framework for action. J. Environ. Manag. 2019, 240, 47-56. [CrossRef] [PubMed]

4. Abedin, S.J.H.; Stephen, H. GIS framework for spatiotemporal mapping of urban flooding. Geosciences 2019, 9, 77. [CrossRef]

5. Ngang, C.P.; Hashim, H.S.; Pereira, J.J. Climate change mitigation and adaptation as a sustainable regional development strategy: Lessons from the Selangor River basin, Malaysia. Int. J. Malay World Civ. 2017, 5 , 43-52.

6. Surwase, T.; Manjusree, P. Urban flood simulation- A case study of Hyderabad city. In Proceedings of the National Conference on Flood Early Warning for Disaster Risk Reduction, Hyderabad, India, 30-31 May 2019; pp. 133-143.

7. Rabori, A.M.; Ghazavi, R. Urban flood estimation and evaluation of the performance of an urban drainage system in a semi-arid urban area using SWMM. Water Environ. Res. 2018, 90, 2075-2082. [CrossRef]

8. Samsuri, N.; Abu Bakar, R.; Unjah, T. Flash flood impact in Kuala Lumpur-Approach review and way forward. Int. J. Malay World Civ. 2018, 6, 69-76.

9. Morris, K.I.; Chan, A.; Morris, K.J.K.; Ooi, M.C.G.; Oozeer, M.Y.; Abakr, Y.A.; Nadzir, M.S.M.; Mohammed, I.Y.; Al-Qrimli, H.F. Impact of urbanization level on the interactions of urban area, the urban climate, and human thermal comfort. Appl. Geogr. 2017, 79, 50-72. [CrossRef]

10. Gülbaz, S.; Kazezyılmaz-Alhan, C.M. An evaluation of hydrologic modeling performance of EPA SWMM for bioretention. Water Sci. Technol. 2017, 76, 3035-3043. [CrossRef]

11. Li, G.F.; Xiang, X.Y.; Tong, Y.Y.; Wang, H.M. Impact assessment of urbanization on flood risk in the Yangtze River Delta. Stoch. Environ. Res. Risk Assess. 2013, 27, 1683-1693. [CrossRef]

12. Odunuga, S.; Raji, S.A. Flood frequency analysis and inundation mapping of lower Ogun River basin. J. Water Resour. Hydraul. Eng. Sept. 2014, 3, 48-59.

13. Yazdi, M.N.; Ketabchy, M.; Sample, D.J.; Scott, D.; Liao, H. An evaluation of HSPF and SWMM for simulating streamflow regimes in an urban watershed. Environ. Model. Softw. 2019, 118, 211-225. [CrossRef] 
14. Wanniarachchi, S.S.; Wijesekera, N.T.S. Using SWMM as a tool for floodplain management in ungauged urban watershed. Eng. J. Inst. Eng. Sri Lanka 2012, 45, 1-8. [CrossRef]

15. Xiao, D.; Chen, M.; Lu, Y.; Yue, S.; Hou, T. Research on the construction method of the service-oriented web-SWMM system. ISPRS Int. J. Geo-Inf. 2019, 8, 268. [CrossRef]

16. Arnbjerg-Nielsen, K.; Willems, P.; Olsson, J.; Beecham, S.; Pathirana, A.; Bülow Gregersen, I.; Madsen, H.; Nguyen, V.T.V. Impacts of climate change on rainfall extremes and urban drainage systems: A review. Water Sci. Technol. 2013, 68, 16-28. [CrossRef] [PubMed]

17. Bharati, L.; Gurung, P.; Jayakody, P.; Smakhtin, V.; Bhattarai, U. The projected impact of climate change on water availability and development in the Koshi basin, Nepal. Mt. Res. Dev. 2014, 34, 118-130. [CrossRef]

18. Toriman, M.E.; Hassan, A.J.; Barzani Gazim, M.; Mokhtar, M.; Mastura, S.A.S.; Jaafar, O.; Karim, O.; Aziz, N.A.A. Integration of 1-D hydrodynamic model and GIS approach in flood management study in Malaysia. Res. J. Earth Sci. 2009, 1, 22-27.

19. Yusoff, I.M.; Ramli, A.; Mhd Alkasirah, N.A.; Mohd Nasir, N. Exploring the managing of flood disaster: A Malaysian perspective. Malays. J. Soc. Space 2018, 14, 24-36. [CrossRef]

20. Diya, S.G.; Kamarudin, M.K.A.; Gasim, M.B.; Toriman, M.E.; Juahir, H.; Umar, R.; Saudi, A.S.M.; Abdullahi, M.G.; Rabiu, A.A. Flood simulation model using XP-SWMM along Terengganu River, Malaysia. J. Fundam. Appl. Sci. 2018, 9, 66-81. [CrossRef]

21. Dutsenwai, H.S.; Ahmad, B.B.; Mijinyawa, A.; Yusof, K.B.W. Fusion of SAR images for improved classification of flooded areas in the Northern Peninsular Malaysia. Res. J. Appl. Sci. Eng. Technol. 2015, 11, $259-266$. [CrossRef]

22. Chan, N.W. Increasing flood risk in Malaysia: Causes and solutions. Disaster Prev. Manag. An Int. J. 1997, 6, 72-86. [CrossRef]

23. Klang Municipal Council Draf Rancangan Tempatan Majlis Perbandaran Klang (Pengubahan 1) 2020; Klang Municipal Council: Klang, Malaysia, 2011.

24. Adeoti, L.; Odunuga, S.; Adegbola, R.B.; Oladele, S.; Raji, S.A. Effect of flood analysis on the foundation investigation using integrated approach. In Proceedings of the International Conference on Engineering Geophysics, Al Ain, UAE, 15-18 November 2015; pp. 240-243.

25. Toriman, M.E.; Juahir, H.; Mokhtar, M.; Gazim, M.B.; Abdullah, S.M.S.; Jaafar, O. Predicting for discharge characteristics in Langat River, Malaysia using neural network application model. Res. J. Earth Sci 2009, 1, 15-21.

26. Shaaban, A.J.; Amin, M.Z.M.; Chen, Z.Q.; Ohara, N. Regional modeling of climate change impact on Peninsular Malaysia water resources. J. Hydrol. Eng. 2010, 16, 1040-1049. [CrossRef]

27. Toriman, M.E.; Mokhtar, M.B.; El-fithri, R.; Aziz, N.A.A.; Abdullah, M.P.; Gasim, M.B. Impact of climate change on regional hydroclimate projection in Peninsular Malaysia. J. Environ. Sci. Eng. 2012, 1, $43-47$.

28. Izham, M.Y.; Uznir, U.; Alias, A.R.; Ayob, K. Georeference, rainfall-runoff modeling and 3D dynamic simulation: Physical influence, integration and approaches. In Proceedings of the 1st International Conference and Exhibition on Computing for Geospatial Research \& Application, Washington, DC, USA, 21-23 June 2010.

29. Memarian, H.; Balasundram, S.K.; Talib, J.B.; Sood, A.M.; Abbaspour, K.C. Trend analysis of water discharge and sediment load during the past three decades of development in the Langat basin, Malaysia. Hydrol. Sci. J. 2012, 57, 1207-1222. [CrossRef]

30. Hohmann, C.; Birk, S.; Kirchengast, G. Alpine foreland running drier? Sensitivity of a drought vulnerable catchment to changes in climate, land use, and water management. Clim. Chang. 2018, 179-193. [CrossRef]

31. Juahir, H.; Zain, S.M.; Yusoff, M.K.; Hanidza, T.I.T.; Armi, A.S.M.; Toriman, M.E.; Mokhtar, M. Spatial water quality assessment of Langat River basin (Malaysia) using environmetric techniques. Environ. Monit. Assess. 2011, 173, 625-641. [CrossRef]

32. Yang, H.; Jaafar, O. Impact of land-use changes toward base-flow regime in Lui and Langat Dengkil sub-basin. Int. J. Phys. Sci. 2011, 6, 4960-4976.

33. Kwak, D.; Kim, H.; Han, M. Runoff control potential for design types of low impact development in small developing area using XPSWMM. Procedia Eng. 2016, 154, 1324-1332. [CrossRef]

34. Department of Irrigation and Drainage. Laporan Banjir Selangor: Daerah Klang. 2014. Available online: http://apps.water.gov.my/peristiwabanjir/dokumen/laporan_banjir_Klang_26122014.pdf (accessed on 1 October 2019). 
35. Stamatatou, N.; Vasiliades, L.; Loukas, A. The effect of sample size on bivariate rainfall frequency analysis of extreme precipitation. Proceedings 2018, 7, 19. [CrossRef]

36. Thakali, R.; Kalra, A.; Ahmad, S.; Qaiser, K. Management of an urban stormwater system using projected future scenarios of climate models: A watershed-based modeling approach. Open Water J. 2018, 5, 1-16.

37. Jakob, D.; Karoly, D.; Seed, A. Rainfall frequency analysis: Is the assumption of stationarity still valid? In Proceedings of the 9th ICSHMO Conference, Sydney, Australia, 5-9 February 2009; pp. 9-13.

38. Uthman, D.N.A.; Selaman, O.S. Regional rainfall frequency analysis for Samarahan River basin. J. Civ. Eng. Sci. Technol. 2017, 8, 89-95. [CrossRef]

39. Onen, F.; Bagatur, T. Prediction of flood frequency factor for Gumbel distribution using regression and GEP model. Arab. J. Sci. Eng. 2017, 42, 3895-3906. [CrossRef]

40. Guimberteau, M.; Ronchail, J.; Espinoza, J.C.; Lengaigne, M.; Sultan, B.; Polcher, J.; Drapeau, G.; Guyot, J.L.; Ducharne, A.; Ciais, P. Future changes in precipitation and impacts on extreme streamflow over Amazonian sub-basins. Environ. Res. Lett. 2013, 8, 014035. [CrossRef]

41. Alam, M.A.; Emura, K.; Farnham, C.; Yuan, J. Best-fit probability distributions and return periods for maximum monthly rainfall in Bangladesh. Climate 2018, 6, 9. [CrossRef]

42. Ahn, J.; Cho, W.; Kim, T.; Shin, H.; Heo, J.H. Flood frequency analysis for the annual peak flows simulated by an event-based rainfall-runoff model in an urban drainage basin. Water 2014, 6, 3841-3863. [CrossRef]

43. Ajmal, M.; Ahn, J.H.; Kim, T.W. Excess Stormwater quantification in ungauged watersheds using an event-based Modified NRCS model. Water Resour. Manag. 2016, 30, 1433-1448. [CrossRef]

44. Diogo, A.F.; do Carmo, J.A. Peak flows and stormwater networks design-current and future management of urban surface watersheds. Water 2019, 11, 759. [CrossRef]

45. Dhakal, N.; Fang, X.; Thompson, D.B.; Cleveland, T.G. Modified rational unit hydrograph method and applications. Proc. Inst. Civ. Eng. Water Manag. 2014, 167, 381-393. [CrossRef]

46. Department of Irrigation and Drainage Urban Stormwater Management Manual for Malaysia; Department of Irrigation and Drainage: Kuala Lumpur, Malaysia, 2012.

47. Aldalur, B.; Campo, A.; Fernández, S. Urban drainage control applying rational method and geographic information technologies. Cent. Eur. J. Eng. 2013, 3, 497-512. [CrossRef]

48. Pale Kyi, M.; Win Zin, W. Analysis of drainage capacity by using rational method and storm water management model. Int. J. Innov. Res. Multidiscip. Field 2018, 5, 9-14.

49. Keshta, E.; Gad, M.A.; Amin, D. A long-term response-based rainfall-runoff hydrologic model: Case study of the Upper Blue Nile. Hydrology 2019, 6, 69. [CrossRef]

50. Wang, X.; Liu, T.; Li, C.; Zhu, Z.; Zhang, S.; Melesse, A.M. Development of a modified rational equation for arid-region runoff estimation. In Proceedings of the World Environmental and Water Resources Congress, Palm Springs, CA, USA, 22-26 May 2011; pp. 4702-4716.

51. Giudice, G.D.; Padulano, R.; Rasulo, G. Spatial prediction of the runoff coefficient in Southern Peninsular Italy for the index flood estimation. Hydrol. Res. 2014, 45, 263-281. [CrossRef]

52. Chin, D.A. Estimating peak runoff rates using the rational method. J. Irrig. Drain. Eng. 2019, 145, 1-8. [CrossRef]

53. Qin, H.P.; Li, Z.X.; Fu, G. The effects of low impact development on urban flooding under different rainfall characteristics. J. Environ. Manag. 2013, 129, 577-585. [CrossRef] [PubMed]

54. Bisht, D.S.; Chatterjee, C.; Kalakoti, S.; Upadhyay, P.; Sahoo, M.; Panda, A. Modeling urban floods and drainage using SWMM and MIKE URBAN: A case study. Nat. Hazards 2016, 84, 749-776. [CrossRef]

55. Jiang, L.; Chen, Y.; Wang, H. Urban flood simulation based on the SWMM model. Proc. IAHS 2015, 368, 186-191. [CrossRef]

56. Tu, M.C.; Smith, P. Modeling pollutant buildup and washoff parameters for SWMM based on land use in a semiarid urban watershed. Water. Air. Soil Pollut. 2018, 229, 121. [CrossRef]

57. Nam, W.; Shin, H.; Jung, Y.; Joo, K.; Heo, J.H. Delineation of the climatic rainfall regions of South Korea based on a multivariate analysis and regional rainfall frequency analyses. Int. J. Climatol. 2015, 35, 777-793. [CrossRef]

58. Genovese, E. A Methodological Approach to Land Use-Based Flood Damage Assessment in Urban Areas: Prague Case Study. Eur. Communities, DG-JRC, Ispra, EUR. 2006, 39. Available online: https://www.unisdr. org/files/2678_EUR22497EN.pdf (accessed on 1 September 2019). 
59. Junaidi, L.M.; Ermalizar, L.M.; Junaidi, A. Flood simulation using EPA SWMM 5.1 on small catchment urban drainage system. MATEC Web Conf. 2018, 229, 1-9. [CrossRef]

60. Yin, J.; Yu, D.; Yin, Z.; Liu, M.; He, Q. Evaluating the impact and risk of pluvial flash flood on intra-urban road network: A case study in the city center of Shanghai, China. J. Hydrol. 2016, 537, 138-145. [CrossRef]

61. Gao, P.; Li, P.; Zhao, B.; Xu, R.; Zhao, G.; Sun, W.; Mu, X. Use of double mass curves in hydrologic benefit evaluations. Hydrol. Process. 2017, 31, 4639-4646. [CrossRef]

62. Wang, W.; Shao, Q.; Yang, T.; Peng, S.; Xing, W.; Sun, F.; Luo, Y. Quantitative assessment of the impact of climate variability and human activities on runoff changes: A case study in four catchments of the Haihe River basin, China. Hydrol. Process. 2012, 26, 1-16. [CrossRef]

63. Dhakal, K.P. Climate Change Impact on Urban Stormwater System and Use of Green Infrastructure for Adaptation: An Investigation on Technology, Policy, and Governance. Ph.D. Thesis, Southern Illinois University, Carbondale, IL, USA, 2017.

64. Macro, K.; Matott, L.S.; Rabideau, A.; Ghodsi, S.H.; Zhu, Z. OSTRICH-SWMM: A new multi-objective optimization tool for green infrastructure planning with SWMM. Environ. Model. Softw. 2019, 113, 42-47. [CrossRef]

65. Rezaei, A.R.; Ismail, Z.; Niksokhan, M.H.; Dayarian, M.A.; Ramli, A.H.; Shirazi, S.M. A quantity-quality model to assess the effects of source control stormwater management on hydrology and water quality at the catchment scale. Water 2019, 11, 1415. [CrossRef]

66. Weaver, E.R.R.; Nachabe, M.H. Parameters sensitivities for sustainable urban infrastructure. Proc. Inst. Civ. Eng. Munic. Eng. 2019, 172, 73-82. [CrossRef]

67. Knighton, J.; Lennon, E.; Bastidas, L.; White, E. Stormwater detention system parameter sensitivity and uncertainty analysis using SWMM. J. Hydrol. Eng. 2016, 21, 05016014. [CrossRef]

68. Hossain, S.; Hewa, G.A.; Wella-Hewage, S. A comparison of continuous and event-based rainfall-runoff (RR) modelling using EPA-SWMM. Water 2019, 11, 611. [CrossRef]

69. Hlustik, P. Practical assessment of the SWMM programme. In Proceedings of the IOP Conference Series: Earth and Environmental Science, Ostrava, Czech Republic, 28-30 November 2017; Volume 92, p. 12018.

70. Mohammed, T.A.; Ghazali, A.H.; Othman, S.; Sidek, L.M. Evaluation of XP-SWMM sub-models in predicting flood for a tropical urban catchment. In Proceedings of the 11th International Conference on Urban Drainage, Scotland, UK, 31 August-5 September 2008; Volume 11, pp. 846-856.

71. Mark, O.; Weesakul, S.; Apirumanekul, C.; Aroonnet, S.B.; Djordjević, S. Potential and limitations of 1D modelling of urban flooding. J. Hydrol. 2004, 299, 284-299. [CrossRef]

72. Huang, Y. Rapid flood risk assessment using GIS technology. Int. J. River Basin Manag. 2009, 7, 3-14. [CrossRef]

73. Kottegoda, N.T.; Natale, L.; Raiteri, E. Monte Carlo Simulation of rainfall hyetographs for analysis and design. J. Hydrol. 2014, 519, 1-11. [CrossRef]

74. Huong, H.T.L.; Pathirana, A. Urbanization and climate change impacts on future urban flooding in Can Tho city, Vietnam. Hydrol. Earth Syst. Sci. 2013, 17, 379-394. [CrossRef]

75. Zakaria, N.A.; Ghani, A.A.; Abdullah, R.; Sidek, L.M.; Kassim, A.H.; Ainan, A. A new urban stormwater management manual for Malaysia. Adv. Hydro-Sci. Eng. 2014, VI, 1-10.

76. Wang, C.; Zheng, S.S.; Wang, P.F.; Hou, J. Interactions between vegetation, water flow and sediment transport: A review. J. Hydrodyn. 2015, 27, 24-37. [CrossRef]

77. Toriman, M.E.; Ata, F.M.; Kamarudin, M.K.A.; Idris, M. Bed-load sediment profile and effect of river bank erosion on river cross-section. Am. J. Environ. Sci. 2013, 9, 292-300. [CrossRef]

(C) 2019 by the authors. Licensee MDPI, Basel, Switzerland. This article is an open access article distributed under the terms and conditions of the Creative Commons Attribution (CC BY) license (http://creativecommons.org/licenses/by/4.0/). 